\title{
Identification and Genetic Diversity of Lake Sturgeon Larvae on Artificial Reefs in the Huron-Erie Corridor
}

Jamie Marie Marranca

West Virginia University

Follow this and additional works at: https://researchrepository.wvu.edu/etd

\section{Recommended Citation}

Marranca, Jamie Marie, "Identification and Genetic Diversity of Lake Sturgeon Larvae on Artificial Reefs in the Huron-Erie Corridor" (2014). Graduate Theses, Dissertations, and Problem Reports. 240.

https://researchrepository.wvu.edu/etd/240

This Thesis is protected by copyright and/or related rights. It has been brought to you by the The Research Repository @ WVU with permission from the rights-holder(s). You are free to use this Thesis in any way that is permitted by the copyright and related rights legislation that applies to your use. For other uses you must obtain permission from the rights-holder(s) directly, unless additional rights are indicated by a Creative Commons license in the record and/ or on the work itself. This Thesis has been accepted for inclusion in WVU Graduate Theses, Dissertations, and Problem Reports collection by an authorized administrator of The Research Repository @ WVU. For more information, please contact researchrepository@mail.wvu.edu. 


\title{
Identification and Genetic Diversity of Lake Sturgeon Larvae on Artificial Reefs in the Huron-Erie Corridor
}

\author{
Jamie Marie Marranca \\ Thesis submitted to the \\ Davis College of Agriculture, Natural Resources, and Design \\ at West Virginia University \\ in partial fulfillment of the requirements \\ for the degree of \\ Master of Science \\ in \\ Wildlife and Fisheries Resources
}

\author{
Amy Welsh, Ph.D. \\ Patricia M. Mazik, Ph.D. \\ Edward F. Roseman, Ph.D. \\ Wildlife and Fisheries Resources \\ Division of Forestry and Natural Resources
}

Morgantown, WV

2014

Keywords: lake sturgeon, Acipenser fulvescens, St. Clair River, Detroit River, conservation, habitat restoration, genetics, microsatellites, assignment testing, founder effect 


\title{
ABSTRACT \\ Identification and Genetic Diversity of Lake Sturgeon Larvae on Artificial Reefs in the Huron-Erie Corridor
}

\author{
Assignment Testing of Larval Lake Sturgeon from Three Artificial Reefs
}

\&

\author{
Founder Effect Analysis of Larval Lake Sturgeon from Three Artificial Reefs
}

\author{
Jamie Marie Marranca
}

There are 27 species of sturgeon worldwide and most are currently extinct, endangered or threatened. Lake sturgeon, Acipenser fulvescens, one of the oldest species on the planet, evolved about 136 million years ago, and have had little morphological change, and are endemic to the freshwater lakes and rivers created by receding glaciers of the Laurentian ice sheet. Lake sturgeon have seen immense habitat loss due to human development and industrialization has nearly decimated populations. Changes to water and habitat quality, along with overharvesting, have caused declines to nearly $1 \%$ of their original population size. The Huron-Erie Corridor (HEC), includes the St. Clair and Detroit rivers that connect the upper and lower Great Lakes. This area in particular has experienced adverse effects over nearly 200 years of human activities, including the removal of spawning habitat to accommodate shipping traffic. Conservation efforts include regulations, endangered species listing, and habitat reconstruction. The creation of artificial reefs may be a sustainable management option by allowing the fish to increase their population sizes naturally. Three artificial reefs were built in the HEC in hopes of replacing spawning habitat. To verify the success and efficacy of the artificial reefs, genetics were used to determine the source and numbers of adult lake sturgeon spawning on the reefs and to determine if genetic diversity is maintained in their offspring. The maintenance of genetic diversity is required to expand population sizes and prevent negative side effects, such as the founder effect, in future generations. Eggs were collected from each reef and hatched into larvae in the lab. DNA was extracted from larval tail clips and PCR was performed to amplify 12 microsatellite loci. The samples were run using a capillary electrophoresis to obtain allele sizes at each locus for each individual. Their genotypes were then compared to 22 previously studied adult lake sturgeon populations in the Great Lakes to determine where the parental population came from. The effective population sizes for each reef were calculated to determine how many adults successfully spawned on each reef. The larval genotypes were then compared to the source population to determine if there were any losses in genetic diversity by calculating observed heterozygosity, allelic richness, and inbreeding coefficients that are indicative of the founder effect. The St. Clair and Detroit River adult populations were found to be the source parental population for the larvae collected on all three artificial reefs. There were large numbers of contributing adults when compared to total population sizes within the Great Lakes. There was no loss in genetic diversity in the larval samples compared to their parents, and therefore no evidence of the founder effect. This supports continued protection of lake sturgeon spawning habitat as well as the construction of additional reefs in the HEC. 
ACKNOWLEDGEMENTS:

I am very grateful for the help of many people involved in the funding, assistance, and completion of this project.

\author{
Dr. Amy Welsh, WVU (advisor) \\ Dr. Edward Roseman, USGS (committee) \\ Dr. Pat Mazik, USGS, WVCFWRU (committee) \\ Dr. George Merovich, WVU \\ Dr. Pierre Duchesne, Université Laval \\ Dr. Bruce Manny, USGS \\ James Boase, USFWS Fisheries Biologist \\ Justine Whitaker, WVU graduate student \\ Darren Wood, WVU graduate student \\ Justin Chiotti, USFWS \\ USGS Great Lakes Research Science Center, Ann Arbor Michigan \\ USFWS Alpena Fish and Wildlife Conservation Office, Alpena Michigan \\ Michigan Sea Grant \\ Huron-Erie Corridor Initiative
}

Funding for this project was provided by the Great Lakes Restoration Initiative Project Template 70, Developing Fish Habitat Enhancement Strategies for the Huron-Erie Corridor and the USGS Great Lakes Science Center. 
Table of Contents

Chapter 1. Lake Sturgeon Life History, Threats and Conservation in the Great Lakes and the Huron-Erie Corridor

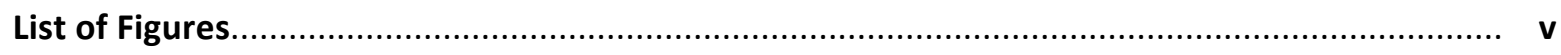

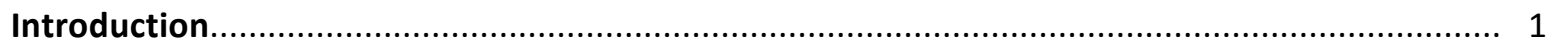

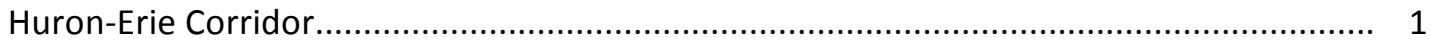

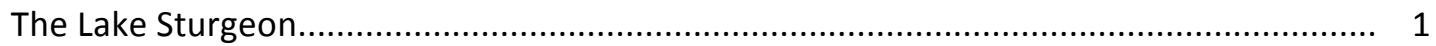

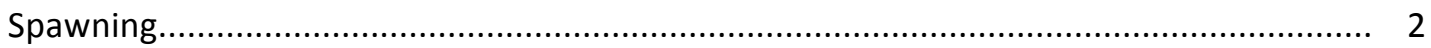

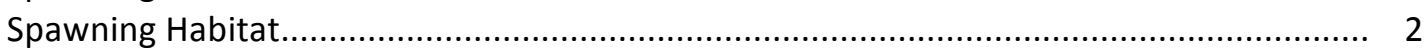

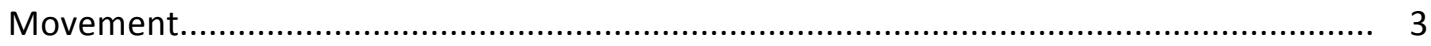

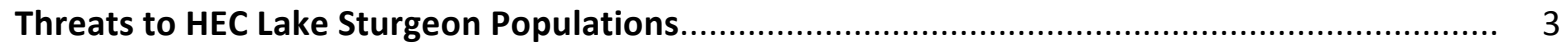

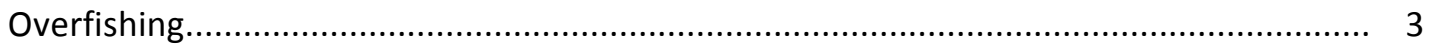

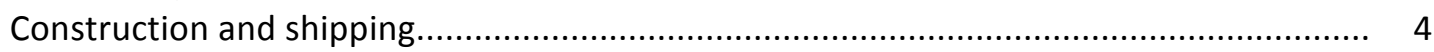

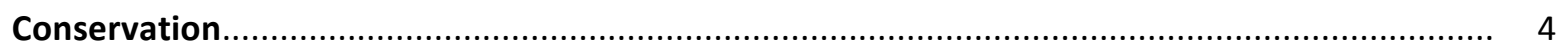

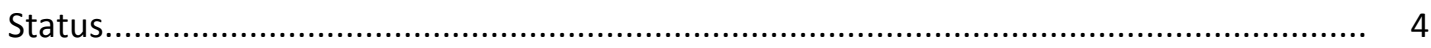

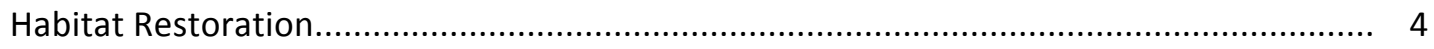

HEC Artificial Reefs............................................................................................. 5

Genetics

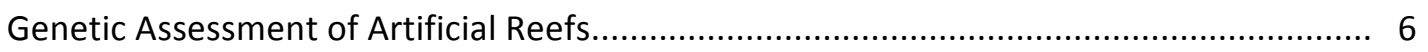

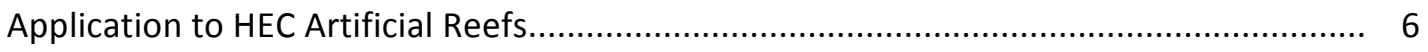

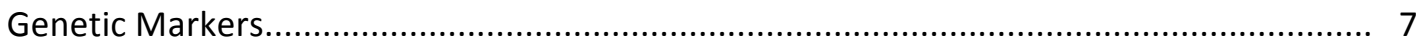

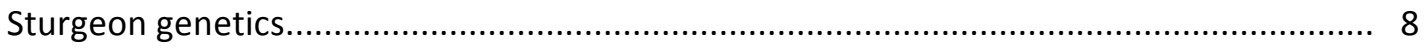

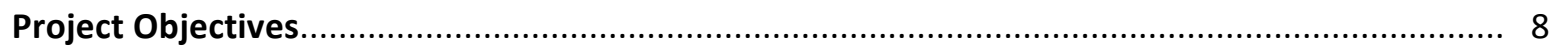

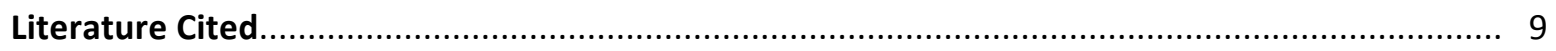




\section{List of Figures}

Figure 1. This map shows the position of the three artificial reefs and their years of construction in the St. Clair and Detroit rivers that make up the HEC (adapted from the Michigan Sea Grant).

Figure 2. The map on the left depicts the natural ecosystem in 1815 that included surrounding wetlands along the Detroit River. On the right is a current satellite image of the landscape after 200 years of industrialization and development of the shoreline of the Detroit River (adapted from Association of Canada Map Libraries and Google Satellite Image).

Figure 3. Pictures captured during the altering of the river bed to accommodate shipping traffic. The top picture shows the natural river bottom while water was diverted. These rocks provided ample spawning habitat for lake sturgeon. The bottom picture was taken after the natural bottom was removed so the shipping channel could be widened and deepened (source: Library of Congress).. 20 
Chapter 2: Assignment Testing of Larval Lake Sturgeon, Acipenser fulvescens, from Three Artificial Reefs

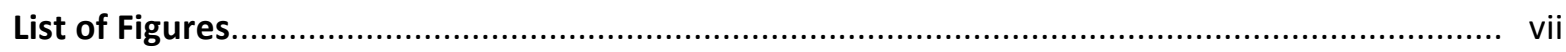

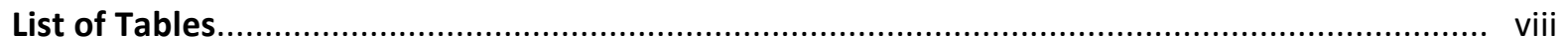

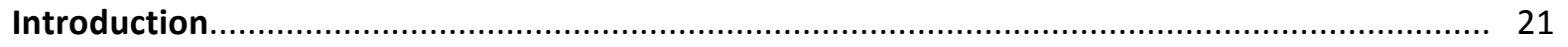

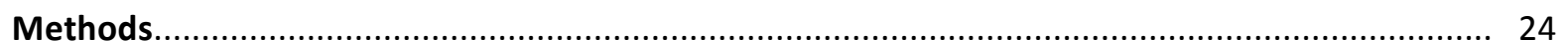

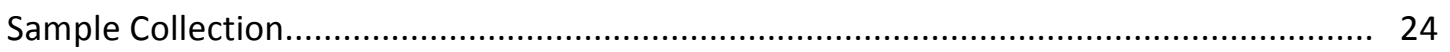

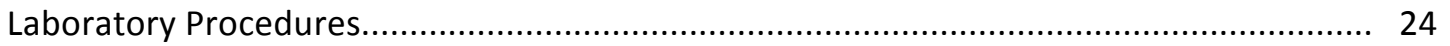

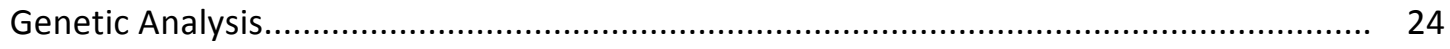

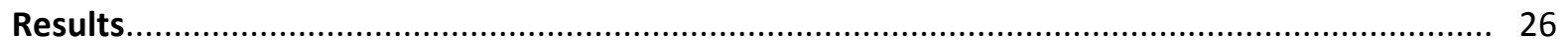

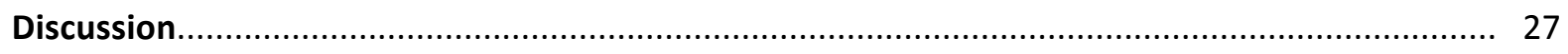

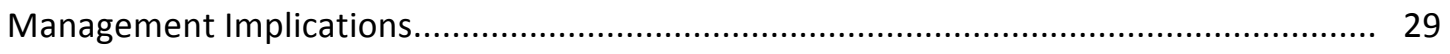

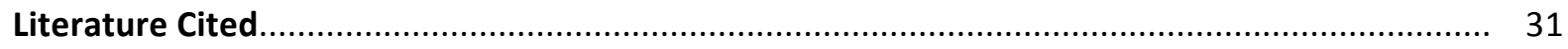




\section{List of Figures}

Figure 4. This map shows the position of the three sampled artificial reefs and the year of construction in the St. Clair and Detroit rivers that make up the HEC. (adapted from the Michigan Sea Grant)... 36

Figure 5. This satellite image shows the location of the 22 potential source populations distributed throughout the upper Great Lakes as described in Welsh et al. (2008). The Northern sites from Kaministiqua to East Nipissing are located in Ontario, Canada. The White down to Wolf are in Wisconsin and the Manistee, Muskegon and Kalamazoo are located in Michigan. The red box surrounds the study area: the HEC.

Figure 6. A. Results from Structure Harvester depicting a $k=2$ population structure. B. A $k=2$ bar plot STRUCTURE result showing Fighting Island (1) with the final five potential sources by site: East Nipissing (2), West Nipissing (3), Spanish (4), Detroit (5), and St. Clair (6) rivers.

Figure 7. A. Results from Structure Harvester depicting a $k=2$ population structure. B. A $k=2$ bar plot STRUCTURE result showing Fighting Island (1) with the final two potential sources by region: Detroit-St. Clair rivers (2) and Nipissing sites (3).

Figure 8. A. Results from Structure Harvester depicting a $k=2$ population structure. B. A $k=2$ bar plot STRUCTURE result showing Maslankas larvae (1) with the final five potential sources by site: Detroit (2), St. Clair (3), Manistee (4), Muskegon (5), and Kalamazoo rivers (6). 40

Figure 9. A. Log (K) graph of the number of possible populations and the variance associated with each (provided as additional support for $k=2$ ). B. Delta $\mathrm{K}$ results from Structure Harvester depicting a $k=2$ population structure. C. A $k=2$ bar plot STRUCTURE result showing Maslanksas larvae (1) with the final two potential sources by region: Detroit-St. Clair rivers (2) and Eastern Michigan

Figure 10. A. $\log (\mathrm{K})$ graph of the number of possible populations and the variance associated with each (provided as additional support for $k=2$ ). B. Results from Structure Harvester depicting a $k=2$ population structure. C. A $k=2$ bar plot STRUCTURE result showing Middle Channel larvae (1) with the final five potential sources by site: East Nipissing (2), West Nipissing (3), Spanish (4), Detroit (5), and St. Clair (6) rivers.

Figure 11. A. Results from Structure Harvester depicting a $k=2$ population structure. B. A $k=2$ bar plot STRUCTURE result showing Middle Channel larvae (1) with the final three potential sources by region: North Channel (2), Nipissing (3), and Detroit-St. Clair rivers (4).

Figure 12. This tree was created using the results from FLOCK analyzing the artificial reefs with the 22 possible sites in the upper Great Lakes. Each arrow represents a run resulting in $k=2$. Yellow boxes surround sites that were removed due to the program's inability to cluster them confidently. All other boxes contain sites that were grouped by similarity. 44

Figure 13. This tree was created using the results from FLOCK analyzing the artificial reefs with the eight possible source regions in the upper Great Lakes. Each arrow represents a run resulting in $k=2$. Yellow boxes surround regions that were removed due to the program's inability to cluster them confidently. All other boxes contain sites that were grouped by similarity. 


\section{List of Tables}

Table 1. Locus names, sequences, allele sizes, the number of alleles, and the dye used for all 12 microsatellite loci.

Table 2. PCR information: locus, PCR protocol (described in Table 3), annealing temperature, and group for capillary electrophoresis. * corresponds to the following charts in which the annealing temperature is programmed to change with each cycle in the PCR protocol.

Table 3. Thermocycler programs for each of the three cycles to amplify the microsatellite loci..... 48

Table 4. ONCOR assignment results of mixture analysis of Fighting Island, Maslankas, and Middle Channel reefs by site and by region. Percent assignment is given with 95\% confidence intervals.. 49

Table 5. ONCOR individual assignment results for Fighting Island, Maslankas, and Middle Channel reefs. The percent accuracy is the individuals that could be assigned meeting an $80 \%$ cut off value. Of those, the percent assigned to the Detroit or St. Clair rivers or the Detroit-St. Clair region are listed in the third column. The other column shows the origin and number of individuals from the artificial reefs that assigned to another population. 50

Table 6. GeneClass2 simulation results using the reference regions using Rannala and Mountain (1997). Each region is listed with the population size, the percentage of correct assignment (\% accuracy). The individuals that assigned to regions are listed in the "other assigned" column with the region name and number of individuals that assigned to it. 51

Table 7. GeneClass2 simulation results using the reference regions using Baudouin and LeBrun (2001). Each region is listed with the population size, the percentage of correct assignment (\% accuracy). The individuals that assigned to regions are listed in the "other assigned" column with the region name and number of individuals that assigned to it

Table 8. GeneClass2 results of the artificial reefs by region using the Rannala and Mountain (1997). The population size $(\mathrm{N})$ for each reef is given with the percent of individuals assigned and the percent of assignment to each region. The individuals that assigned to regions are listed in the "other assigned" column with the region name and number of individuals that assigned to it. 
Chapter 3: Founder effect analysis of larval lake sturgeon, Acipenser fulvescens, from three artificial reefs

List of Figures.

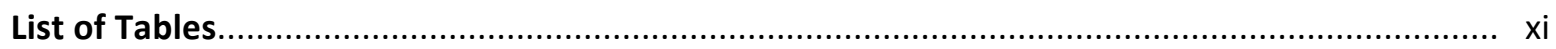

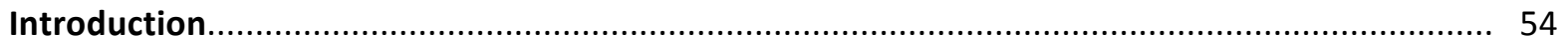

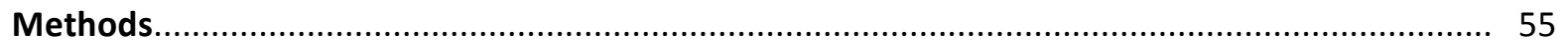

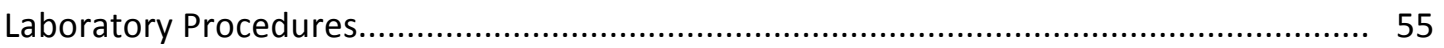

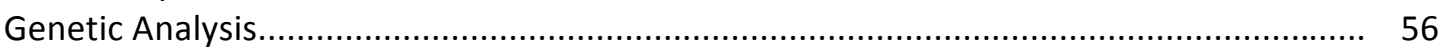

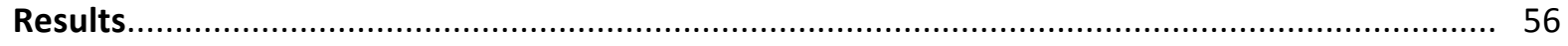

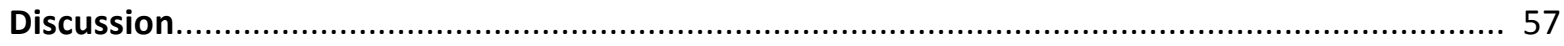

Management Implications........................................................................ 59

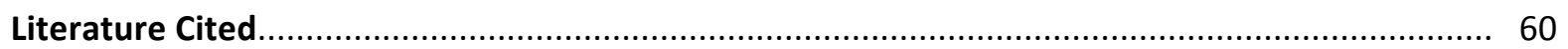




\section{List of Figures}

Figure 13. Each of these graphs depicts the tested genetic diversity of the three artificial reefs and their source population: the Detroit and St. Clair rivers and the Detroit-St. Clair region. The bars depict heterozygosity, allelic richness, and inbreeding coefficient averaged across 12 loci...................... 64 


\section{List of Tables}

Table 9. The genetic diversity measures averaged across loci of Fighting Island, Maslankas, and Middle Channel reefs and the Detroit River, St. Clair River, and the Detroit-St. Clair region.

65

Table 10. These tables show the results of tests for significance using the paired t-test. Each reef is compared to the source region and both source sites for observed heterozygosity, allelic richness, and $F_{\text {is. }}$ Significant results are highlighted in yellow. 
Chapter 1. Lake Sturgeon Life History, Threats and Conservation in the Great Lakes and the Huron-Erie Corridor

\section{INTRODUCTION}

There are 27 species of sturgeon worldwide and most are currently extinct, endangered or threatened. Lake sturgeon, Acipenser fulvescens, one of the oldest species on the planet, evolved about 136 million years ago, and have had little morphological change, and are endemic to the freshwater lakes and rivers created by receding glaciers of the Laurentian ice sheet. Lake sturgeon have seen immense habitat loss due to human development and industrialization has nearly decimated populations. Changes to water and habitat quality, along with overharvesting, have caused declines to nearly $1 \%$ of their original population size. The Huron-Erie Corridor (HEC) includes the St. Clair and Detroit rivers that connect the upper and lower Great Lakes. This area in particular has experienced adverse effects over nearly 200 years of human activities, including the removal of spawning habitat to accommodate shipping traffic. Conservation efforts include regulations, stocking, endangered species listing, and habitat reconstruction. The creation of artificial reefs may be a more sustainable alternative to stocking by allowing the fish to increase their population sizes naturally. Three artificial reefs were built in the Huron-Erie Corridor in hopes of replacing spawning habitat. To verify the success and efficacy of the artificial reefs, genetics were used to determine the source and numbers of adult lake sturgeon spawning on the reefs and to determine if genetic diversity is maintained in their offspring. The maintenance of genetic diversity is required to expand population sizes and prevent negative side effects, such as the founder effect, in future generations.

The Huron-Erie Corridor: The St. Clair River (64 kilometers long), Lake St. Clair, and the Detroit River (45 kilometers long) make up the south-flowing waterways connecting the upper and lower Great Lakes, providing a major shipping channel as well as opportunities for recreational, commercial, and industrial uses. The natural bottom substrate consists of sand, silt and clay in the St. Clair or gravel, bedrock and boulders with soft substrates in the Detroit River (US Army Corps of Engineers 1998, Boase et al. 2011). The St. Clair River is deeper than the Detroit with depths ranging from 9-21 meters and fastest where Lake Huron empties into it. It shallows to approximately 1.5 meters naturally after splitting into three main channels before discharging into Lake St. Clair. Depths in the Detroit River reach 16 meters with water velocities ranging from $0.75-1.68 \mathrm{~m} / \mathrm{s}$. The rivers of the Huron-Erie Corridor (HEC) have endured drastic land use changes from wetlands and forests to the creation of walled shorelines containing industry, docks, urbanization and industrialization on the American side and industry, and urbanization and agriculture on the Canadian side (Manny 2003).

The Lake Sturgeon: Lake sturgeon are a large, long-lived fish. Natural mortality is low once they become juveniles as there are no natural predators, but they have high mortality rates as eggs and larvae (Carrofino et al. 2010, Forsythe et al. In review). They are estimated to live 50 to 150 years of age for males and females, respectively (Hayes and Carrofino 2012). Because they are slow-growing fish, they grow longer before they gain weight. As they age, the reverse is true. Their growth is also dependent on spawning, slowing prior to spawning and increasing just after (Roussow 1957, Baker 1980). Adults can grow to 1.8 meters in length and weigh over 90.7 kilograms, with females usually being the largest. It is likely that because females live longer than males, this explains the higher ratio of females to males (Fortin et al. 1993). 
Lake sturgeon are opportunistic feeders; specific prey consumption varies by location, season and prey abundance. Lake sturgeon feed on small fish, benthic invertebrates, mollusks, fish eggs, and insect larvae throughout the year, though consumption tends to slow during winter months in northern populations (Choudhury et al. 1996). The barbels assist in locating food since their ability to see in the water column is limited beyond its rostrum. The larvae depend solely on their yolk sac when first hatched as most organs and features have not yet developed. Waters less than 9 meters typically contain the most abundant food sources for these fish (Priegel and Wirth. 1971). Food availability may also determine habitat selection (Chiasson et al. 1997).

These ancient fish were once abundant from the Great Lakes and Hudson Bay to the Mississippi River. Today, population sizes in the northern reaches are a fraction of their former numbers, but vary depending on anthropogenic disturbances, habitat quality and local protections. They are very particular in habitat choice, and habitat preference changes with age and season. Vegetation inhibits their ability to capture food, so they prefer barren, sandy substrate for feeding. Adults are found in a wide variety of habitats, taking advantage of seasonal and water condition changes. Lake sturgeon are usually observed close to spawning sites, but it is suspected that they migrate to deeper waters during summer months and daytime hours (Auer, 2011).

Spawning: A long life-cycle necessitates delayed maturation. Males reach sexual maturity around 15 years of age while females can take up to 30 years to mature (Priegel and Wirth 1971, Bruch 1999, Bruch et al. 2001, Bruch 2002). This provides ample time for the fish to reach a large enough size to limit mortality and maximize reproductive output (Beamesderfer and Farr 1997, Peterson et al. 2007). Males spawn every 1-5 years and females every 3-9 years, significantly different from most other fish which spawn annually (Roussow 1957, Priegel and Wirth 1971, Fortin et al. 1996, Bruch 2002). Shorter spawning cycles have been documented and may be due to warmer temperatures, faster growth due to high food abundance, or isolated populations (Auer 1999). Photoperiod and lunar cycles have been implicated in endocrine level changes in spawning individuals that can trigger spawning (Takemura et al. 2004, Forsythe et al. 2010, Forsythe et al. 2012b). Sturgeon have also been shown to potentially be reproductively isolated by timing, with individuals arriving on preferred reefs during particular environmental cues (Forsythe 2012a). Due to longevity and spawning periodicity in lake sturgeon, reproductively active individuals in a population can span approximately 20 age classes allowing for protection against short-term environmental disturbances (Peterson et al. 2007).

Lake sturgeon have a unique mating ritual. One year before spring spawning, the fish migrate towards a staging ground in their natal rivers and streams. When the water temperature nears $13^{\circ} \mathrm{C}$, a female will move to a spawning site where 2 to 8 males arrived 1-2 days prior (Auer 1996b, Bruch and Binkowski 2002, Smith and King 2005, Peterson et al. 2007). Fertile adults are extraordinarily sensitive to temperature changes resulting in delayed or discontinued spawning. Spawning can occur deeper in the water column, but usually takes place just under the surface (Priegel and Wirth, 1971). Males take turns striking the female with their tails to stimulate egg release until she has expelled them all (Priegel and Wirth 1971, Bruch and Binkowski 2002, Peterson et al. 2007).

Spawning Habitat: Sturgeon require specialized habitats for successful reproduction. During spawning season, the water must not only remain at a temperature range of $11-16^{\circ} \mathrm{C}$, but must flow rapidly over spawning sites (Auer 1996a, Bruch and Binkowski 2002) to prevent clumping of eggs causing suffocation and disease (Ferguson and Duckworth 1997, Hay-Chmielewski and Whelan 1997). Sturgeon use plantfree, sloping shorelines consisting of rocks and small gravel to a depth of more than a half a meter to lay their eggs (Auer 1999). As the adhesive eggs are laid, they spread out in the current across the substrate 
surface. Immediately after spawning, which can take up to 12 hours, the females move out of the spawning area to slower and deeper water (Boase et al. 2011).

Males remain until all fertile females have left the spawning area. While exact reasons for this desertion are unknown, it is hypothesized that movement is necessary for food access, growth efficiency, increased fitness, or protection of larvae from consumption (Auer 1999, Peterson et al. 2007). Eggs hatch in about 10 days, but hatch rate increases with warmer temperatures (Kempinger 1988). Larvae sink down into the interstitial spaces of the substrate. It has been documented that between 2 and 3 weeks of age in smaller systems, when the water temperature reaches at least $16^{\circ} \mathrm{C}$, the larvae emerge and disperse between the bottom and mid-depth downstream at night (Smith and King 2005), although larvae have not been observed behaving in this manner in every system (Priegel and Wirth 1974, Wallus 1990, Bouckaert 2013).

Movement: Migration and dispersal differ between populations, some being sedentary by choice or by barrier, and some migrating long distances. Migration and dispersal tendencies, as well as habitat preferences, may be different between males and females. Lake sturgeon have been found to migrate over $200 \mathrm{~km}$ from their natal rivers (Wilson, 2004). Even within sedentary populations, the fish move in the boundaries of their home system and within the water column (Boase et al. 2011). Depth changes are related to photoperiod, season, and even shipping traffic (Hay-Chmielewski 1987, Priegel and Wirth 1971, Engel 1990).

There have been several studies attempting to determine migration patterns in lake sturgeon, however, aside from spawning migration, movements appear to be random (Harkness and Diamond 1961, Priegel and Wirth 1974, Peterson et al. 2007). It is hypothesized that some movements are influenced by avoidance of changing water conditions and searches for winter habitat (Bajkov 1930, Peterson et al. 2007). Since these fish do not feed during spawning, it is also possible that migration is prompted by the need for food after relying on lipid stores during that time (Harkness and Dymond 1961, McKinley et al. 1998, Peterson et al. 2007).

Homing tendencies have been documented in many populations (Priegel and Wirth 1971, Thomas and Haas 2002, Caswell et al. 2004) and create unique populations adapted to different behaviors and habitats (Auer, 1996). Other species have been shown to migrate, or stray, even when they demonstrate natal fidelity, therefore it is likely that a proportion of free-moving populations migrate (Homola et al. 2010). In the Huron-Erie Corridor, there is a telemetry study in progress to determine the dispersal habits and habitat use of adults that spawn in the area (GLATOS 2012-2017).

\section{THREATS TO HEC LAKE STURGEON POPULATIONS}

Human impacts have caused a decline in lake sturgeon to nearly $1 \%$ of their former numbers due to overharvesting, habitat loss and degradation, dams, and water pollution (Hay-Chmielewski and Whelan 1997). In the Huron-Erie Corridor, overfishing and habitat loss due to channelization are the primary reasons for this decline.

Overfishing: Native Americans regularly ate lake sturgeon, but for nearly 400 years, European settlers avoided this food source unless experiencing famine (Saffron 2004). Lake sturgeon were found to be a nuisance at first, getting caught in fouling fishing nets designed for the preferred catch of the time. They were generally tossed aside becoming pig feed, burnable fuel for ships, or left on river shores to rot. 
Fisheries were established in the 1860s for the purpose of extracting roe for caviar that was exported to Europe or eaten by immigrant populations in New England. They also harvested swim bladders for isinglass, used in the food and drink industry as clarifiers, and meat that was found to be a suitable substitute for halibut. The exploitation of lake sturgeon continued until the fishing industry imploded in the early 1900s, having exhausted most of its supply and was no longer profitable. In the Ontario waters of the Huron-Erie Corridor, lake sturgeon fishing, recreational and commercial, is closed all year (Ontario Ministry of Natural Resources 2009). In Michigan, recreational anglers are limited to one lake sturgeon per year between July 15 and November 7 with a 127 centimeter minimum (Michigan Department of Natural Resources by sections 41101 through 41105 of 1994 PA 451, as amended, being MCL 324.41101 through 41105) and commercial fishing has been banned since 1977 (Hayes and Caroffino 2012).

Construction and Shipping: The shipping industries contributed greatly to habitat loss and pollution within the Great Lakes and tributaries. Harbor construction and shipping traffic changed sediment dispersal, affecting migration and spawning site selection for the fish. The HEC was drastically altered between 1874 and 1964 to accommodate shipping by removing gravel and boulders, widening and straightening, and deepening. The original depth of the Detroit River was around 4 meters, but by creating coffer dams and drilling and blasting out the original limestone substrate, more than 9.5 million cubic yards of river bottom were removed (US Army Corps of Engineers 1998). The shipping channel is maintained at a minimum constant depth of 8 meters (Boase et al. 2011). Due to the removal and movement of the naturally occurring substrates, islands and dikes were created, deep holes were filled in, and natural water flows altered (Fig 1). Sediment movement created sandbars hidden just beneath the surface in many areas.

\section{CONSERVATION}

Status: Currently, lake sturgeon are not federally protected in the United States or Canada, but tend to have some protections at the state and provincial level with support towards federal listing. They are considered threatened or endangered in Ontario and in all but one U.S. state of 20 in their historic range(Auer 1991, Roseman et al. 2011). Regulations exist in both countries banning or limiting commercial fisheries, limiting recreational fishermen to catch and release, catch and keep during limited months, or slot limits, and protecting or rebuilding spawning habitat. Special interest groups have formed to assist in educating the public and even stand guard at known spawning sites to prevent poaching (e.g. Lake Winnebago Sturgeon Guard Program; Sturgeon for Tomorrow). In the study area considered in this thesis, lake sturgeon are listed as "threatened" under the State of Michigan's Endangered Species Act (Section 36505 (1a), Part 324, Endangered Species Protection, of Act No. 451 of the Public Acts of 1994), "threatened" by the Committee on the Status of Species at Risk in Ontario (Ontario Ministry of Natural Resources 2009), and are listed under CITES Appendix II since 1997 (Williamson 1997).

Habitat Restoration: In some areas, it has been common practice to stock threatened or economically important species. While there is new credence given to the genetic sustainability of these stocked fish, stocking remains an ongoing and expensive process that ignores the underlying problems causing declines perpetuating the need to restock (Trushenksi et al. 2010). Hatchery fish are also highly prone to disease, parasites, and declining health due to rearing in close proximity, contaminated feed, and unforeseen rearing system problems or changes (USFWS Region 3 Fisheries Data Series 2006). In Oregon in 2012, the cost of running 32 Atlantic salmon hatcheries was 25 million dollars in one year alone, $70 \%$ in federal dollars and $24 \%$ combined in licensing and power company contributions. In 
comparison, the cost of an artificial reef may be approximately $\$ 500,000$ per half hectare and an additional $\$ 250,000$ per year for two years pre and post build scientific monitoring (E. Roseman personal communication).

There have been concerns raised about the genetic integrity of stocking hatchery-raised fish (Tringali and Bert 1998). Crossman et al. $(2010,2011)$ found that lake sturgeon hatcheries were producing more genetically similar and less fit offspring, and in turn, decreasing the number of different breeding individuals. The collection of eggs, through handling, from migrating wild females has been shown to interrupt natural spawning either entirely or only partially releasing eggs (Crossman 2008). Hatcheries may also be missing additional spawning events within a given year which may naturally contribute to additional genetic diversity within a population (Forsythe 2012).

Lake (2001) noted that humans damage ecosystems at a much faster rate than they can be restored and made clear the importance of pre- and post-restoration assessments. In the case of the Great Lakes, the scale of habitat loss among other anthropogenic changes is immense. To find a more sustainable solution to population declines, scientists and managers have adopted a strategy to rehabilitate and rebuild habitats. While assessing restoration attempts for lake sturgeon, managers have found that successful reproduction in the Great Lakes system is limited by spawning habitat (Auer 1996, Daugherty et al. 2008). In these studies, the habitats were analyzed for species richness, life stage use, and breeding effectiveness, and the results were then used to create new objectives until an ideal spawning habitat was recreated.

Artificial reefs are becoming increasingly popular in the aquatic world, with methods ranging from sinking decommissioned ships to altering and carefully placing non-natural materials in both salt and fresh water environments. They may have originally started to lure fish for harvest (Tarzwell 1937), but are used now for recreational use and species restoration. There are several suggestions for creating successful new habitats through restoration (Fuchs and Stazner 1990, Kerr et al. 2011). Fuchs and Statzner (1990) explored time requirements for population improvements in large river systems. While managers can plan and implement habitat changes, there are other unforeseen issues, such as chemical spills, that extend the time needed to see marked improvement of species. Dispersal is the main behavior that affects colonization of new habitat by natural source populations (Riley and Fausch 1995). The rate at which this happens is dependent on distances between current habitat and new habitat as most species tend to stay within smaller, confined regions (Kareiva 1990, Bunn and Hughes 1997).

HEC Artificial Reefs: Wisconsin created the first sets of spawning habitats that are now widely accepted as suitable for lake sturgeon. Scientists in the HEC adopted these plans and have created three spawning reefs in the Detroit River and are in the process of building up to ten more in the St. Clair and Detroit rivers. The first was built in 2004 at Belle Isle near Detroit. While adult lake sturgeon have been seen on this reef, the spawning of other ecologically and economically important species has been confirmed (Read and Manny 2006, Manny et al. 2007). The lack of spawning by lake sturgeon served as a learning opportunity for future spawning reefs in the area. In 2008, the Fighting Island spawning reef was built in the Detroit River (Roseman et al. 2011) with cooperation between the state of Michigan, the province of Ontario, U.S. federal agencies, and several local and regional agencies, universities and private organizations. In the St. Clair River, Middle Channel reef was built in 2012 with yet more subtle changes learned from Fighting Island reef assessments. As part of the post-restoration assessments, adult lake sturgeon were documented spawning on both reefs the spawning season after completion, and on Middle Channel reef during construction. Eggs and larvae have been collected, but accurate estimates of spawning adults have not yet been obtained. 


\section{GENETICS}

Genetic Assessment of Artificial Reefs: The choice of a management plan, such as the creation of artificial reefs, needs to be based on the needs of a population and an understanding of the genetic relationships and requirements of populations, or subpopulations, in order to have long-term success. Long term success is defined by not only use of a habitat, but by maintaining the genetic diversity required for survival and population growth. Habitat restoration requires a comprehension of not only habitat requirements limiting life cycles but also of population and family structure in a region. Genetic information can provide information that may be otherwise unavailable due to the inability to observe populations and behaviors. Delineating populations and subpopulations can also provide population size estimates, mating success, and distribution (Waples 1990, Taylor et al. 2001, Planes et al. 2002). Genetic diversity must be maintained among and within populations to ensure fitness and survival, and each population must be treated as its own unit to achieve this (Waples 1990, Meffe and Carroll 1997, McQuown et al. 2003).

Application to HEC Artificial Reefs: Genetic diversity of newly-established populations in the HEC needs to be assessed to determine the success of the artificial reefs. The first goal is to compare the genetic diversity of the larvae from the reefs to adult populations in the Great Lakes to determine who the parental population is. Due to the range of lake sturgeon movement, the adults contributing to the offspring are of unknown origin. In order to understand their origins and determine management objectives, it is important to calculate the genetic diversity of new populations since it is altered by forces such as migration and drift (Whitlock 2011). Migrating individuals may contribute new alleles to a population (Wright 1943). Since lake sturgeon have a tendency towards spawning in a home range, mating occurs not just between individuals on one reef, but possibly multiple reefs within a system (Forsythe et al. 2012, Forsythe et al. 2012, J. Holtgren, personal communication).

The second goal is to determine if there is a loss in genetic diversity in the larval population. Genetic drift is a natural occurrence of random mating that shifts allele frequencies in a population through generations towards eliminating gene variation. The rate of loss in a population is dependent on the number of spawning individuals, the effective population size: the smaller the effective population size, the faster alleles are lost. Thus, smaller populations are prone to a rapid loss of genetic diversity. The founder effect is an extreme example of genetic drift and occurs when a small number of adults reproduce in a new location creating a new population. When there are few adults, the alleles those spawning individuals carry are not representative of the whole population and become more prominent in the new population. This leads to reduced genetic variation in the new populations as well as non random samples of genes compared to the original population. In some instances, this founder effect can be so significant that it can result in mutation (Hastbacka et al. 1991, Ebers et al. 1995, Haywood et al. 2013) or when mixed with selection and other evolutionary driving forces, speciation (Barton and Charlesworth 1984, Carson and Templeton 1984, Giddings et al. 1987, Howard and Berlocher 1998, Wade et al. 2000, Bird Life International 2012). While long-lived species tend to be shielded from the loss of genetic diversity (Hailer et al. 2006), in small populations, the long-lived species can be more vulnerable to increased genetic drift because it takes more time for the population size to grow (Ennen et al. 2011). In either example, the results can be especially important when considering endangered species or already small populations. Genetic drift occurs faster in small populations or in populations with low genetic diversity, decreasing time to fixation with its potential negative side effects. 
Inbreeding can decrease reproduction and survival of species as first noted by Darwin (1876) by decreasing the genetic diversity and potentially decreasing sperm production, fecundity, age at sexual maturity, and survival (Ralls and Ballou 1983, Lynch and Walsh 1998, Frankham et al. 2002). Decreasing genetic diversity creates populations that are unable to adapt to changing environments, a global conservation concern, or to disease and parasites (Frankham and Kingslover 2004, Frankham 2005). A compilation of studies done by Crnokrak and Roff (1999) showed $90 \%$ of taxa experienced low reproductive fitness due to inbreeding. While full sibling inbreeding has been shown to increase the risk of extinction (Frankham 1995b, Reed et al. 2002, 2003), partial relatedness inbreeding increases extinction risk at slower rates. Therefore, in order for conservation efforts to work, inbreeding of wild populations must be avoided.

Genetic Markers: Previous genetic studies of lake sturgeon were attempted using mitochondrial DNA (mtDNA), a maternally inherited marker not influenced by recombination. MtDNA was successfully used to determin00e two recolonization events by lake sturgeon that occurred after the glaciers receded (Billington and Herbert 1991). However, the results of population structure studies have varied using mtDNA. Ferguson et al. (1993) and Ferguson and Duckworth (1997) found few polymorphic sites indicating low genetic variability but DeHaan et al. (2006) found high numbers of polymorphic sites indicating more genetic variability. While there are many copies of mtDNA throughout a genome, the low variation between individuals and their maternal inheritance makes studying population structure difficult (Wan et al. 2004, Zhang and Hewitt 2003). The use of mtDNA may also result in underestimates of genetic diversity within populations (Zhang and Hewitt 2003), making them unreliable for use in management strategies.

Subsequent studies established the use of microsatellites and found that populations within the Great Lakes are genetically distinct from one another (McQuown et al. 2003, DeHaan et al. 2006, Welsh et al. 2008). Microsatellites are genome-wide, codominant, nearly neutral nuclear markers that are extremely variable due to their high mutation rate and can be obtained through non-lethal sampling (Litt and Luty 1989, Tautz 1989, Bruford and Wayne 1993, Estoup et al. 1993, Weber and Wong 1993, May et al. 1997, Wan et al. 2004). Though first discovered in the human and fruit fly genomes, they have since been proven useful, accurate, and cost effective in non-mammalian species studies of populations, relatedness, and genetic diversity (Miesfeld et al. 1981, Tautz 1989, Bruford and Wayne 1993, Hughes and Queller 1993, Scribner et al. 1994). They have not been shown to be under selective pressure, although there is speculation that microsatellites might be linked to genes that are under selective pressure and can affect gene expression (Kashi and King 2006, Vinces et al. 2009, Gemayel et al. 2010).

High levels of variability are maintained by slippage during DNA replication (Tautz 1989, Amos et al. 1993). Slippage is an event that occurs during the replication of repeated DNA sequences which results in the inadvertent addition or removal of repeats by DNA polymerase. This is also the reason for PCR artifacts, but those are relatively easy to discern from real PCR products in modern technologies. The variability achieved through genetic drift or migration leads to differentiation of alleles at any particular locus that can be used to determine genetic structure between individuals (Bruford and Wayne 1993). One benefit to using microsatellites is the ability to use previously established information in closely related species (Moore et al. 1991). Another possible benefit is that there is no required minimum number of loci for any particular study as long as there are a significant number of alleles available at each locus (Kalinowski 2002). 
Sturgeon genetics: Sturgeon species are polyploid, having more than 2 pairs of homologous chromosomes (Ludwig et al. 2001, Pyatskowit et al. 2001, Schreier et al. 2011) and lake sturgeon are tetraploid, having four copies of each chromosome. Microsatellite work with polyploids can be complex due to the presence of null alleles, the difficulty in accurately determining copy number, as well as requiring complicated analysis that must be confirmed through subsequent testing (Ludwig et al. 2001, Pyatskowit et al. 2001). Furthermore, most analysis packages available are based on the assumption of disomic inheritance. Fortunately, lake sturgeon have a proportion of disomic loci - one copy from each parent (Pyatskowit et al. 2001, Welsh et al. 2003) although they make up a small percentage of all loci (Welsh and May 2006). The detection of these loci enables sturgeon to be studied using the same techniques available to diploid species.

\section{PROJECT OBJECTIVES}

There are two objectives to this study: 1). Determine the source population of lake sturgeon using the artificial reefs for spawning and 2). Determine if the founder effect has resulted in low genetic diversity in the larval population. Due to the tendency for lake sturgeon to remain in a home range, it is suspected that the adults spawning on these reefs are inhabitants of the HEC. Considering the large natural population size of this area, it would be unlikely that the founder effect resulted in the loss of genetic diversity in the new population. 


\section{Literature Cited}

Alberta Sustainable Resource Development. 2002. Status of the Lake Sturgeon (Acipenser fulvescens) in Alberta. Alberta Sustainable Resource Development, Fish and Wildlife Division, and Alberta Conservation Association, Wildlife Status Report No. 46, Edmonton, AB.

Amos, B., Schlotterer, C., and Tautz, D., 1993. Social structure of pilot whales revealed by analytical DNA profiling. Science. 260: 670-672.

Antoniou, A., P. D. P., Pharoah, P.D.P., Narod, S., Risch, H.A.J., Eyfjord, E., Hopper, J.L., Loman, N., Olsson, H., Johannsson, O., Borg, Å., Pasini, B., Radice, P., Manoukian, S., Eccles, D.M., Tang, N., Olah, E., Anton-Culver, H., Warner, E., Lubinski, J., Gronwald, J., Gorski, B., Tulinius, H., Thorlacius, S., Eerola, H., Nevanlinna, H., Syrjäkoski, K., Kallioniemi, O.P., Thompson, D., Evans, C., Peto, J., Lalloo, F., Evans, D. G., Easton, D.F., 2003. Average risks of breast and ovarian cancer associated with BRCA1 and BRCA2 mutations detected in case series unselected for family history: A combined analysis of 22 studies American Journal of Human Genetics. 72(5): 1117-1130.

Auer, N.A., 1996, Importance of habitat and migration to sturgeons with emphasis on lake sturgeon Canadian Journal of Fisheries and Aquatic Science. 53(Suppl. 1): 152-160.

Auer, N.A., 1999, Population Characteristics and Movements of Lake Sturgeon in the Sturgeon River and Lake Superior. Journal of Great Lakes Resources. 25(2): 282-293.

Bajkov, A., 1930. Fishing industry and fisheries investigations in the prairie provinces. Transactions of the American Fisheries Society. 60: 215-237.

Baker, J.P., 1980, The Distribution, Ecology, and Management of the Lake Sturgeon in Michigan, Michigan Department of Natural Resources Fisheries Division, Fisheries Research Report, no 1883.

Barton, N.H., Charlesworth, B., 1984. Genetic revolutions, founder effects, and speciation. Annual Review of Ecology and Systematics. 15: 133-164.

Beamesderfer, R.C.P., Farr, R.A., 1997. Alternatives for the protection and restoration of sturgeons and their habitat. Environmental Biology of Fishes. 48: 407-417.

Billington, N., and Hebert,P.D.N, 1991. Mitochondrial DNA diversity in fishes and its implications for introductions. Canandian Journal of Fisheries and Aquatic Sciences. 48(Suppl. 1): 80-94.

Boase, J.C., Diana, J.S., Thomas, M.V., Chiotti, J.A., 2011. Movements and distribution of adult lake sturgeon from their spawning site in the St. Clair River, Michigan. Journal Applied Ichthyology. 27: 5865.

Bouckaert, E.K., 2013. Verifying success of artificial reefs in the Huron-Erie Corridor for lake sturgeon. Michigan Technological University. 72pp.

Bruch, R.M., 1999. Management of lake sturgeon on the Winnebago System - long term impacts of harvest and regulations on population structure. Journal of Applied Ichthyology. 15: 142-152. 
Bruch, R.M., Dick, T.A., Choudhury, A., 2001. A field guide for the identification of stages of gonad development in lake sturgeon, Acipenser fulvescens Rafinesque, with notes on lake sturgeon reproductive biology and management implications. Publication of Wisconsin Department of Natural Resources. Oshkosh and Sturgeon for Tomorrow. Appleton, WI.

Bruch R.M., Binkowski, F.P., 2002. Spawning Behavior of Lake Sturgeon (Acipenser fulvescens). Journal of Applied Ichthyology. 18: 570-579.

Bruford, M.W., Wayne, R.K., 1993. Microsatellites and their application to population genetic studies. Current Opinion in Genetics and Development. 3: 937-943.

Caroffino. D.C., Sutton, T.M., Elliot, R.F., Donofrio, M.C., 2010. Early life stage mortality rates of lake sturgeon in the Peshtigo River, Wisconsin. North American Journal of Fisheries Management. 30: 295304.

Carson, H.L., Templeton, A.R., 1984. Genetic revolutions in relation to speciation phenomena: the founding of new populations. Annual Review of Ecology and Systematics. 15: 97-131.

Caswell, N.M., Peterson, D.L., Manny, B.A., Kennedy, G.W., 2004. Spawning by lake sturgeon (Acipenser fulvescens) in the Detroit River. Journal of Applied Ichthyology 20: 1-6.

Chiasson, W.B., Noakes, D.L.G., Beamish, F.W.H., 1997. Habitat, benthic prey, and distribution of juvenile late sturgeon (Acipenser fulvescens) in Northern Ontario Rivers. Canadian Journal of Fisheries and Aquatic Sciences. 54: 2866-2871.

Choudry, A., Bruch, R., Dick, T.A., 1996. Helminths and food habits of lake sturgeon Acipenser fulvescens, from the Lake Winnebago system, Wisconsin, American Midland Naturalist. 135(2): 274-282.

Crnokrak, P., Roff, D.A., 1999. Inbreeding depression in the wild. Heredity 83, 260-270.

Crossman, J.A., 2008. Evaluating lake sturgeon (Acipenser fulvescens) restoration programs in the Great Lakes: Effects of collection method, hatchery rearing environment, and age of stocking on genetic diversity, growth, survival, and predation. PhD Dissertation, Michigan State University.

Crossman, J.A., Forsythe, P.S., Baker, E.A., Scribner, K.T., 2010. Hatchery rearing environment and age affect survival and movements of stocked juvenile lake sturgeon. Fish Management Ecology. Published online October 5th 2010.

Crossman, J.A., Scribner, K.T., Yen, D.T., Davis, C.A., Forsyth, P.S., Baker, E.A., 2011. Gamete and laval collection methods and hatchery rearing environment levels of genetic diversity in early life stages of lake sturgeon (Acipenser fulvescens). Aquaculture. 310: 312-324.

Darwin, C., 1876. The effects of cross and self fertilization in the vegetable kingdom. John Murray, London. 
Daugherty, D.J., Sutton, T.M., Elliot, R.F., 2008. Suitability modeling of lake sturgeon habitat in five northern Lake Michigan tributaries: implications of population rehabilitation. Restoration Ecology 17: 245-257

DeHaan, P.W., Libants, S.V., 2006. Genetic population structure of remnant lake sturgeon populations the Upper Great Lakes Basin. Transactions of the American Fisheries Society. 135: 1478-1492.

Dumont, P., Fortin, R., Desjardins, G., Bernard, M., 1987. Biology and exploitation of lake sturgeon (Acipenser fulvescens) in the Quebec waters of the Saint-Laurent River. Pages 57-76 in Proceedings of a workshop on the lake sturgeon (Acipenser fulvescens). Ontario Ministry of Natural Resources Fisheries Technical Report Series No. 23, Toronto, Ontario.

Ebers, G.C., Sadovnick, A.D., Risch, N.J.A., 1995. Genetic basis for familial aggregation in multiple sclerosis. Nature. 377: 150-151.

Engel, M.P., 1990. Population parameters of lake sturgeon in the St. Croix River with special reference to movements. Draft Summary Report, Wisconsin Department of Natural Resources, Madison, WI.

Joshua r. Ennen, roger d. Birkhead, brian r. Kreiser3, daniel I. Gaillard, carl p.

Qualls3, and jeffrey e. Lovich, 2011. The effects of isolation on the demography and genetic diversity of long-lived species: implications for conservation and management of the gopher tortoise (Gopherus polyphemus). Herpetological Conservation and Biology. 6(2): 202-214.

Ferguson, M.M., Bernatchez, L., Gatt, M., Konkle, B.R., Lee, S., Malott, M.L., McKinley, R.S., 1993. Distribution of mitochondrial DNA variation in Lake Sturgeon (Acipenser fulvescens) from the Moose River Basin, Ontario, Canada. Journal of Fish Biology. 43(Supplement A): 91-101.

Ferguson, M.M., Duckworth, G.A., 1997. The Status and Distribution of Lake Sturgeon, Acipenser Fulvescens, in the Canadian Provinces of Manitoba, Ontario and Quebec: A Genetic Perspective, Environmental Biology of Fishes. 48: 299-309.

Fish Propagation Annual Report. 2012. Fish Division. Oregon Department of Fish and Wildlife.

Forsythe, P., K.T. Scribner, J.A. Crossman, A. Ragavendran, and E.A. Baker. Magnitude and sources of lake sturgeon egg mortality in a natural stream setting. Transactions American Fisheries Society. In review.

Forsythe, P.S., J.A. Crossman, N.M. Bello, E.A. Baker, and K.T. Scribner. 2012a. Individual-based analyses reveal high repeatability in timing and location of reproduction in lake sturgeon. Canadian Journal of Fisheries and Aquatic Sciences. 69: 60-72.

Forsythe, P.S., Scribner, K.T., Crossman, J.A., Ragavendran, A., Davis, C., Baker, E.A. , Smith, K.K., 2012b. Environmental and lunar cues are predictive of timing of river entry and spawning site arrival in lake sturgeon. Journal of Fish Biology. 81(1): 35-53.

Fortin, R., Dumont, P., Guenette, S., 1996. Determinants of growth and body condition of lake sturgeon (Acipenser fulvescens). Canadian Journal of Fisheries and Aquatic Sciences. 53: 1150-1156. 
Frankham, R., 1995a. Effective population size/adult population size ratios in wildlife: a review. Genetical Research. 66: 95-107.

Frankham, R., 1995b. Inbreeding and extinction: a threshold effect. Conservation Biology. 9: 792-799.

Frankham, R., Ballou, J.D., Briscoe, D.A., 2002. Introduction to Conservation Genetics. Cambridge University Press, Cambridge.

Frankham, R., Kingslover, J.G., 2004. Response to environmental change: Adaptation or extinction. In: Ferrier, R., Dieckman, U., Couvet, D. (Eds.), Evolutionary Conservation Biology. Cambridge University Press, Cambridge, pp. 85-100.

Fuchs, U., Statzner, B., 1990. Time scales for the recovery potential of riverine communities after restoration: Lessons to be learned from smaller streams. Regulated Rivers: Research and Management. 5: 77-87.

Gemayel, R., Vinces, M.D., Legendre, M., Verstrepen, K.J., 2010. Variable tandem repeats accelerate evolution of coding and regulatory sequences. Annual Review of Genetics. 44: 445-477.

Giddings, Luther V., Kenneth Y. Kaneshiro, and Wyatt W. Anderson, eds. 1989. Genetics, speciation and the founder principle. New York: Oxford Univ. Press.

Groetsch, K.J., Mattes, W.P., Q uinlan, H.R., 2001. Contaminants in Juvenile Lake Superior Lake Sturgeon Muscle: Memo to Neil Kmiecik, Biological Services Director. Great Lakes Indian Fish and Wildlife Commission and US Fish and Wildlife Service.

Hailer, F., Helander, B., Folkestad, A.O., Ganusevich, S.A., Garstad, S., Hauff, P., Koren, C., Nygard, T., Volke, V., 2006. Bottlenecked but long-lived: High genetic diversity retained in white-tailed eagles upon recovery from population decline. Biology Letters. 2(2): 316-319.

Harkness, W.J.K., Dymond, J.R., 1961. The lake sturgeon. Ontario Department of Lands and Forests, Fish and Wildlife Branch, Toronto, 97.

Hart, M. L. 1987. Consideration for the management of lake sturgeon (Acipenser fulvescens) commercial fisheries in Ontario. Pages 85-90 in Proceedings of a Conservation Assessment for Lake sturgeon (Acipenser fulvescens) 19 workshop on the lake sturgeon (Acipenser fulvescens). Ontario Ministry of Natural Resources Fisheries Technical Report Series No. 23, Toronto, Ontario.

Hastbacka, J., Sistonen, P., Kaitila, I., Weiffenbach, B., Kidd, K.K., de la Chapelle, A., 1991. A linkage map spanning the locus for diastrophic dysplasia. Genomics. 11: 968-973.

Haywood, A.F., Merner, N.D., Hodgkinson, K.A., Houston, J., Syrris, P., Booth, V., Connors, S., Pantazis, A., Quarta, G., Elliott, P., McKenna, W., Young, T.L., 2013. Recurrent missense mutations in TMEM43 (ARVD5) due to founder effects cause arrhythmogenic cardiomyopathies in the UK and Canada. European Heart Journal. 34(13): 1002-1011. 
Hay-Chmielewski, E.M., 1987. Habitat preferences and movement patterns of the lake sturgeon (Acipenser fulvescens) in Black Lake, Michigan. Michigan Department of Natural Resources, Fishery Division. Fisheries Research Report No. 1949.

Hay-Chmielewski, E.M., G.E. Whelan, 1997. Lake Sturgeon Rehabilitation Strategy, Michigan Department of Natural Resources, Fisheries Special Report 18.

Hayes, D.B., Caroffino, D.C., 2012, Michigan's lake sturgeon rehabilitation strategy, Michigan Department of Natural Resources, Fisheries Special Report 62, Lansing.

Holtgren, J.M., Auer, N.A., 2011. Movement and habitat of juvenile lake sturgeon (Acipenser fulvescens) in the Lake Sturgeon River/Portage Lake system, Michigan. Journal of Freshwater Ecology. 19: 419-432.

Homola, J.J., Scribner, K.T., Baker, E.A., Auer. N.A., 2010, Genetic Assessment Of Straying Rates Of Wild And Hatchery Reared Lake Sturgeon (Acipenser fulvescens) In Lake Superior Tributaries, Journal of Great Lakes Research. 36: 798-802.

Hästbacka,. J., Sistonen, P., Kaitila, I., Weiffenbach, B., Kidd, K.K., De La Chapelle, A., 1991. A linkage map spanning the locus for diastrophic dysplasia (DTD). Genomics. 11(4): 968-973.

Hughes, C.R., and Queller, D.C., 1993. Detection of highly polymorphic microsatellite loci in a species with little allozyme polymorphism. Molecular Ecology. 2: 131-137.

Hydraulic Discharge Measurements and Regimen Changes on the Great Lakes Connecting Channels and the International Section of the St. Lawrence River. Appendix B: Chronological Summaries of construction and dredging 1841-1993. 1998. US Army Corps of Engineers: Coordinating Committee on Great Lakes Basic Hydraulic and Hydrology Data.

Jager, H.I., Van Winkle, W., Chandler, J.A., Lepla, K.B., Bates, P., Counihan, T.D., 2002. A simulation study of factors Controlling White sturgeon recruitment in the Snake River. In: Van Winkle W, Anders PJ, Secor DH, Dixon DA (eds) Biology, management, and protection of North American sturgeon. American Fisheries Society. Symposium 28. Bethesda, MD. 127-150.

Kashi, Y., King, D.G., 2006. Simple sequence repeats as advantageous mutators in evolution. Trends in Genetics. 22(5): 253-259.

Kempinger, J.J., 1996. Habitat, Growth, and Food of Young Lake Sturgeons in the Lake Winnebago System, Wisconsin. North American Journal of Fisheries Management. 16: 102-114.

Lake, P.S., 2001. On the maturing of restoration. Ecological Management and Restoration. 2(2): 110-115.

Litt M, Luty JA (1989) A hypervariable microsatellite revealed by in vitro amplification of a dinucleotide repeat within the cardiac muscle actin gene. American Journal of Human Genetics. 44: 397-401.

Lynch, M., Walsh, B., 1998. Genetics and Analysis of Quantitative Traits. Sinauer, Sunderland, MA. 
Manny, B.A. 2003. Setting priorities for conserving and rehabilitating Detroit River habitats. In Honoring Our Detroit River: Caring for Our Home, 79-90.

Manny, B.A., Kennedy, G.W., Allen, J.D., French, J.R.P.III., 2007. First Evidence of Egg Deposition by walleye (Sander vitreus) in the Detroit River. Journal of Great Lakes Research 33(2): 512-516.

McKinley, R.S., Van Der Kraak, G., Power, G., 1998. Seasonal migrations and reproductive patterns in the lake sturgeon, Acipenser fulvescens, in the vicinity of hydroelectric stations in northern Ontario. Environmental Biology of Fishes. 51: 245-256.

McQuown, E., Krueger, C.C., Kincaid, H.L., Gall, G.A.E., May, B., 2003. Genetic comparison of lake sturgeon populations: Differentiation based on allelic frequencies at seven microsatellite loci, Journal of Great Lakes Research. 29(1): 3-13.

Meffe, G.K., Carroll, C.R., 1997. Genetics: Conservation of diversity within species. In Principles of Conservation biology, ed. 161-201.

Miesfeld, R., Krystal, M., Arnheim, N.A., 1981. A member of a new repeated sequence family which is conserved throughout eukaryotic evolution is found between the human delta and beta globin genes. Nucleic Acids Research. 9(22): 5931-5947.

Moghim, M., Pourkazemi, M., Tan, S.G., Siraj, S.S., Panandam, J.M., Kor, D., Taghavi, M.J., 2013, Development of disomic single-locus DNA microsatellite markers for Persian Sturgeon (Acipenser persicus) of the Caspian Sea, Canadian Journal of Fisheries Sciences. 12(2) 389-397.

Moore, S.S., Sargeant, L.L., King, T.J., 1991. The conservation of dinucleotide microsatellites among mammalian genomes allows the use of heterologous PCR primer pairs in closely related species. Genomics. 10: 654-660.

Ontario Ministry of Natural Resources. 2009. The lake sturgeon in Ontario. Fish and Wildlife Branch. Peterborough, Ontario. 48 p. + appendices.

Peterson, D.L., Vecsei, P., Jennings, C.A., 2007. Ecology and biology of the lake sturgeon: a synthesis of current knowledge of a threatened North American Acipenseridae, Fish Biology and Fisheries. 17: 59-76.

Planes, S., G. Lacaillon, P. Lenfant, and M. Meekan. 2002. Genetic and demographic variation in new recruits of Naso unicornis. Journal of Fish Biology. 61: 1033-1049.

Priegel, G.R., Wirth, T.L., 1971, The Lake Sturgeon: Its Life Hstory, Ecology and Management, Wisconsin Department of Natural Resources, Publication 240, Madison, WI.

Priegel, G.R., Wirth, T.L., 1974. The lake sturgeon: it's life history, ecology and management. WI Department of Natural Resources Publication 4-3600 (74).

Pyatskowit, J.D., Krueger, C.C., Kincaid, H.L., May, B., 2001, Inheritance of microsatellite loci in the polyploid lake sturgeon (Acipenser fulvescens). Genome. 44: 185-191. 
Ralls, K., Ballou, J., 1983. Extinction: lessons from zoos. In: Schonewald-Cox, C.M., Chambers, S.M., MacBryde, B., Thomas, L. (Eds.), Genetics and Conservation: a Reference for Managing Wild Animal and Plant Populations. Benjamin/Cummings, Menlo Park, CA. pp. 164-184.

Reed, D.H., Briscoe, D.A., Frankham, R., 2002. Inbreeding and extinction: Effects of environmental stress and lineages. Conservation Genetics. 3: 301-307.

Reed, D.H., Lowe, E., Briscoe, D.A., Frankham, R., 2003. Inbreeding and extinction: Effects of rate of inbreeding. Conservation Genetics. 4: 405-410.

Read, J., Manny, B.A., 2006. Belle Isle/Detroit River sturgeon habitat restoration, monitoring, and education project-Monitoring element. Michigan Sea Grant Program. University of Michigan.

Roseman, E.F., Manny, B., Boase, J., Child, M., Kennedy, G., Craig, J., Soper, K., Drouin, R., 2011. Lake sturgeon response to a spawning reef constructed in theDetroit River, Journal of Applied Ichthyology. 27 (Suppl. 2): 66-76.

Roussow, G., 1957. Some considerations concerning sturgeon spawning periodicity, Journal of the Fisheries Research Board of Canada. 14: 553-572.

Saffron I., 2005. The Decline of the North American Species, Introduction. Sturgeons and Paddlefish of North America. Fish \& Fisheries Series. 27: 1-21.

Schreier, A.D., Gille, D., Mahardja, B., May, B., 2011. Neutral markers confirm the octoploid origin and reveal spontaneous autopolyploidy in white sturgeon, Acipenser transmontanus. Journal of Applied Ichthyology. 27(Suppl.2): 24-33.

Scribner, K.T., Arntzen, J.W., and Burke, T. 1994. Comparative analysis of intra- and interpopulation genetic diversity in Bufo bufo, using allozyme, single-locus microsatellite, minisatellite, and multilocus minisatellite data. Molecular Biology and Evolultion. 11: 737-748.

Smith, K.M., King, D.K., 2005, Dynamics and extent of larval lake sturgeon, Acipenser fulvescens, drift in the Upper Black River, Michigan. Journal of Applied Ichthyology. 21: 161-168.

Takemura, A., Rahman, S., Makamura, S., Park, Y.J., and Takano, K. 2004. Lunar cycles and reproductive activity in reef fishes with particular attention to rabbitfishes. Fish and Fisheries. 5: 317-328.

Tarzwell, C.M. 1937. Experimental evidence on the value of trout stream improvement in Michigan. Transaction of the American Fisheries Society. 66: 77-187.

Tautz, D. 1989. Hypervariability of simple sequences as a general source for polymorphic DNA markers. Nucleic Acids Research. 17: 6463-6471.

Taylor, E.B., Redenbach, Z., Costello, A.B., Pollard, S.J.,. Pacas, C.J. 2001. Nested analysis of genetic variation in northwestern North American char, Dolly Varden (Salvelinus malma) and bull trout (Salvelinus confluentus). Canadian Journal of Fisheries and Aquatic Sciences. 58: 406-420.

Thomas, M.V., Haas, R.C., 2002. Abundance, age structure, and spatial distribution of lake 
sturgeon (Acipenser fulvescens) in the St. Clair System. Journal of Applied Ichthyology. 18: 495-501.

Tringali, M.D., Bert, T.M., 1998. Risk to genetic effective population size should be an important consideration in fish stock-enhancement programs. Bull. Mar. Sci. 62, 641-659.

Trushenksi, J., Flagg, T., Kohler, C., 2010. Use of hatchery fish for conservation, restoration, and enhancement of fisheries. Inland fisheries mangement in North America, 3rd edition. American Fisheries Society. 261-293.

US Fish and Wildlife Service. 2006-001. Region 3 Fisheries Data Series. Genoa National Fish Hatchery Lake Sturgeon Culture Standard Operating Procedures.

Vinces, M.D., Legendre, M., Caldara, M., Hagibara, M., Verstrepend, K.J., 2009. Unstable tandem repeats in promoters confer transcriptional evolvability. Science. 324: 1213-1216.

Wallus, R., Simon, T.P., Yeager, B.L., 1990. Family Acipenseridae. Reproductive biology and early life history of fishes in the Ohio River drainage, vol. 1. Acipenseridae through Esocidae. Tennessee Valley Authority, Chattanooga, TN. 29-46.

Wan, Q.H, Wu, H., Fujihara, T., Fang, S.G., 2004. Which genetic marker for which conservation genetics issue? Electrophoresis. 25: 2165-2176.

Waples, R. S. 1991. Heterozygosity and life-history variation in bony fishes: an alternative view. Evolution. 45: 1275-1280.

Weber, J.L., and Wong, C. 1993. Mutation of human short tandem repeats. Human Molecular Genetics. 2: 1123-1128.

Welsh, A., Blumberg, M., and May, B., 2003. Identification of Microsatellite Loci in Lake Sturgeon, Acipenser fulvescens, and their Variability in Green Sturgeon, A. medirostris, Molecular Ecology Notes.

Welsh, A., and May, B., 2006. Development and Standardization of Disomic Microsatellite Markers for Lake Sturgeon Genetic Studies, Journal of Applied Ichthyology. 22: 337-344.

Welsh, A., Hill, T., Quinlan, H., Robinson, C., and May, B., 2008. Genetic Assessment of Lake Sturgeon Population Structure in the Laurentian Great Lakes. North American Journal of Fisheries Management 28: 572-591.

Williamson, D. F. 2003. Caviar and conservation: status, management and trade of North American sturgeon and paddlefish. World Wildlife Fund. Washington, D. C.

Wilson, J.A., McKinley, R.S., 2004, Distribution, habitat and movements, Sturgeon and Paddlefish of North America. 40-72.

Wood, C. 1993. Michigan Fish Contaminant Monitoring Program. 1993 Annual Report. Report \# Michigan/Department of Natural Resources/Surface Water Quality Division-93/059. Lansing, Michigan. 
Zhang, D., Hewitt, G.M., 2003. Nuclear DNA analysis in genetic studies of populations: practice, problems and prospects. Molecular Ecology. 12: 563-584. 


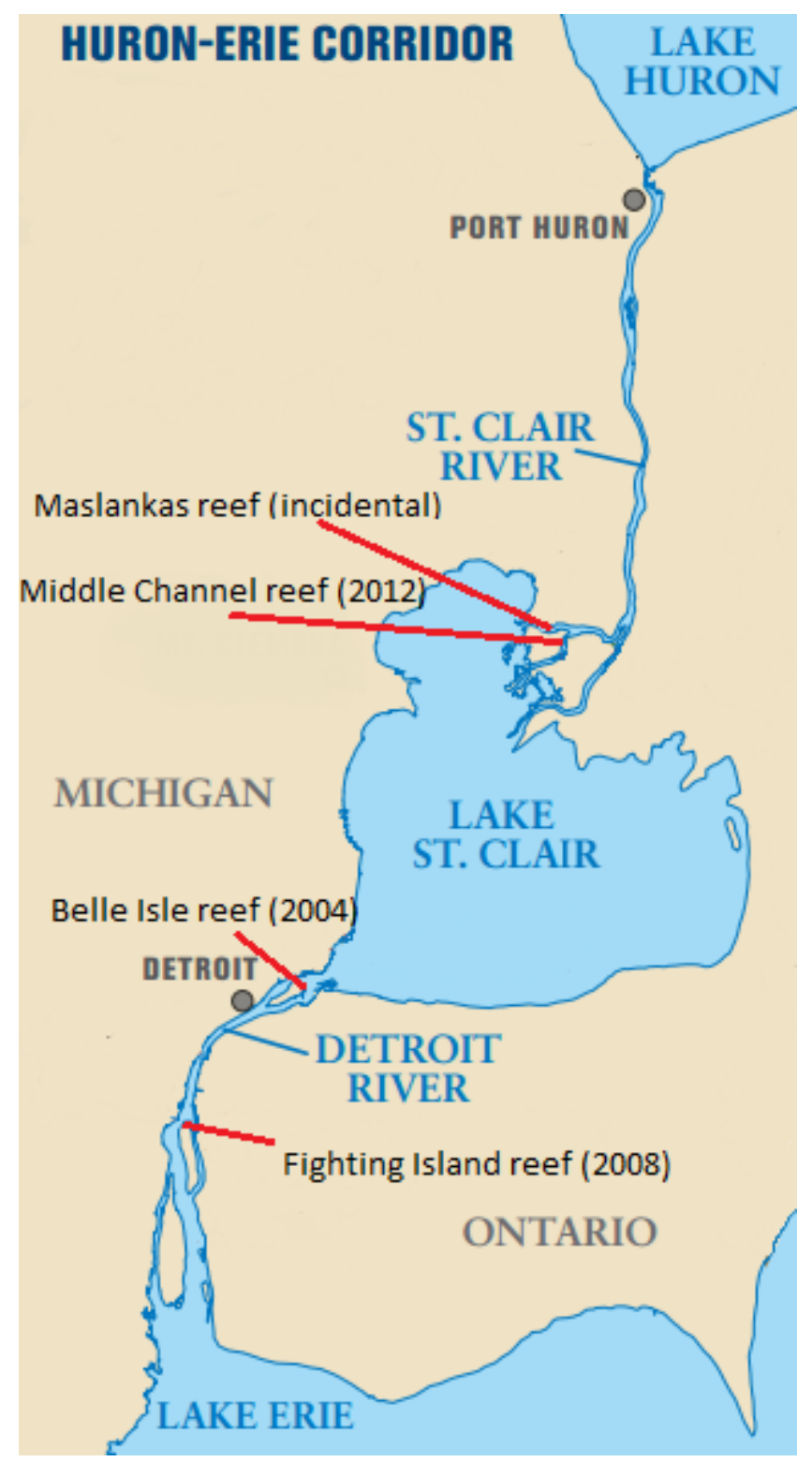

Figure 1. This map shows the position of the three sampled artificial reefs and the year of construction in the St. Clair and Detroit rivers that make up the HEC. (adapted from the Michigan Sea Grant) 

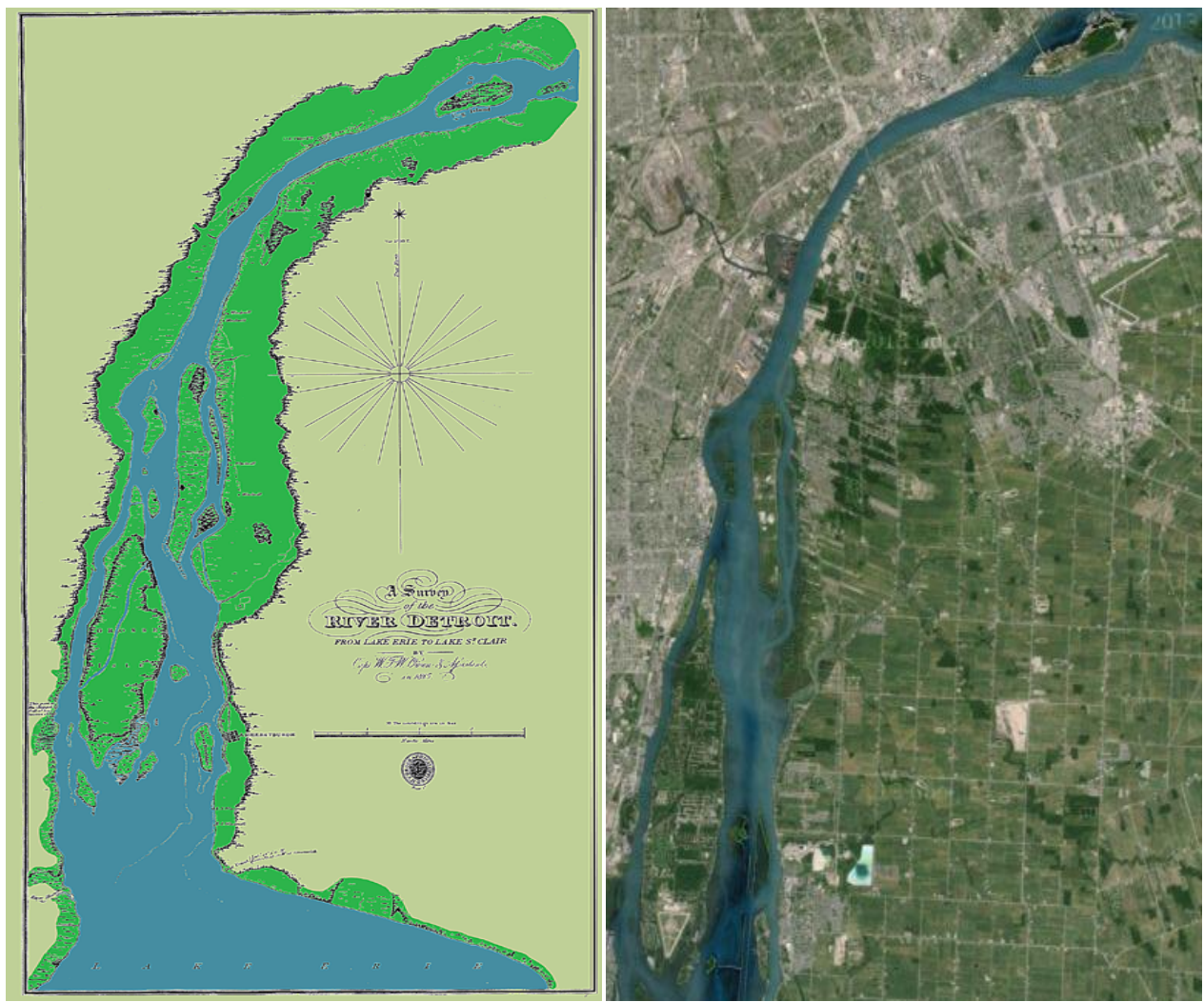

Figure 2. The map on the left depicts the natural ecosystem in 1815 that included surrounding wetlands long the Detroit River. On the right is a current satellite image of the landscape after 200 years of industrialization and development of the shoreline of the Detroit River (left- adapted from Association of Canada Map Libraries and right-Google Satellite Image). 

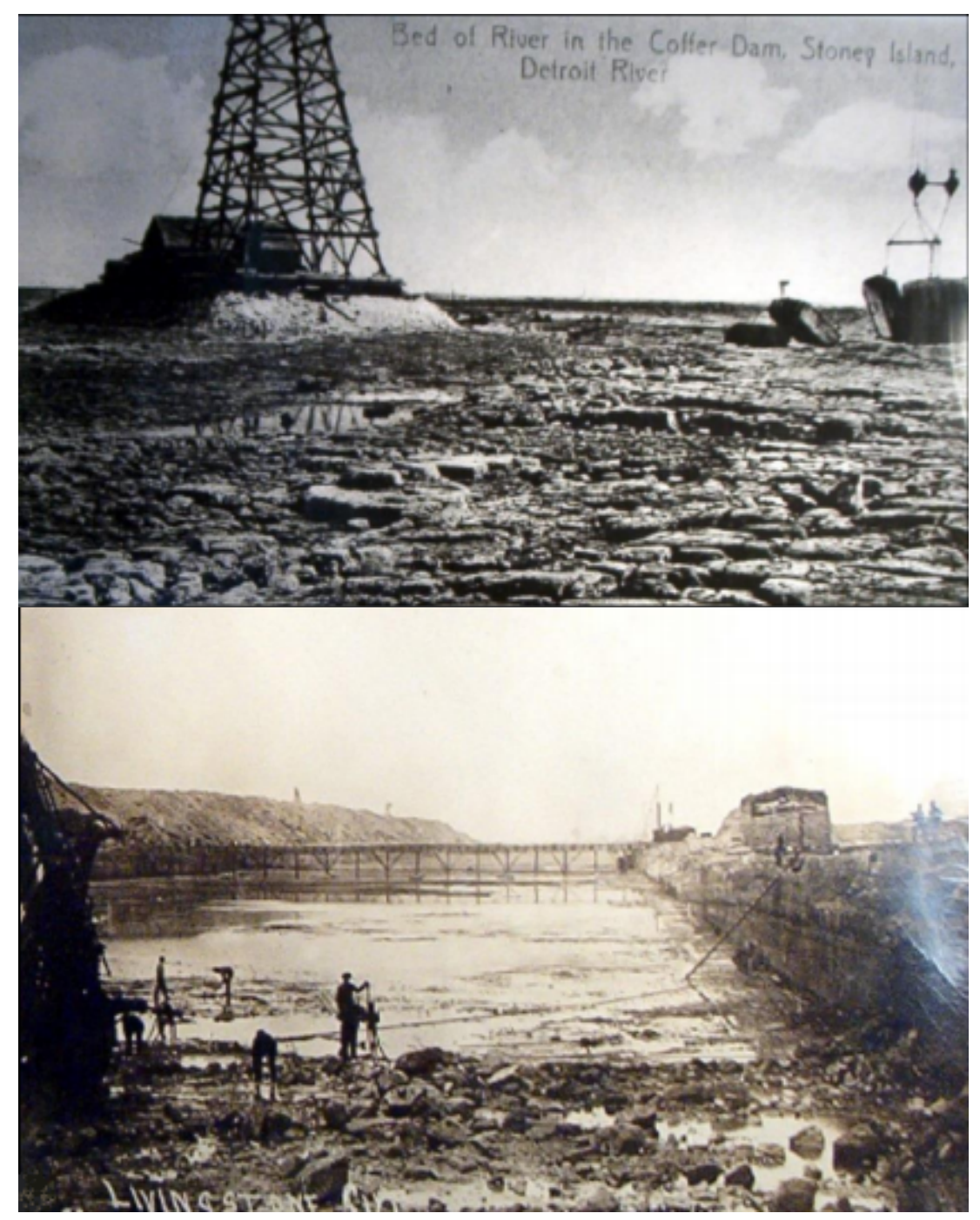

Figure 3. These pictures were captured during the altering of the river bed to accommodate shipping traffic. The top picture shows the natural river bottom while water was diverted. These rocks provided ample spawning habitat for lake sturgeon. The bottom picture was taken after the natural bottom was removed so the shipping channel could be widened and deepened (source: Library of Congress). 
Chapter 2. Assignment Testing of Larval Lake Sturgeon, Acipenser fulvescens, from Three Artificial Reefs

\section{INTRODUCTION}

Lake sturgeon, Acipenser fulvescens, one of the oldest species on the planet, evolved about 136 million years ago, and have had little morphological change. They are endemic to the freshwater lakes and rivers created by receding glaciers of the Laurentian ice sheet. Lake sturgeon have seen immense habitat loss due to human development and industrialization has nearly decimated populations. Changes to water and habitat quality, along with overharvesting, have caused declines to nearly $1 \%$ of their original population size. The Huron-Erie Corridor (HEC) includes the St. Clair and Detroit rivers that connect the upper and lower Great Lakes. This area in particular has experienced adverse effects over nearly 200 years of human activities, including overfishing and the removal of spawning habitat to accommodate shipping traffic. Conservation efforts include regulations, endangered species listing, and habitat reconstruction.

Scientists and managers have switched management plans from stocking to rehabilitate and rebuild natural habitats in order to find economically and ecologically sustainable solutions to the population declines. Two artificial reefs were built in the Huron-Erie Corridor between 2008 and 2012 in hopes of replacing removed spawning habitat. In 2008, the Fighting Island spawning reef was built in the Detroit River with cooperation between the state of Michigan, the province of Ontario, U.S. federal agencies, and several local and regional agencies, universities and private organizations (Roseman et al. 2011). Middle Channel reef was built in 2012 with yet more subtle changes learned from Fighting Island reef assessments. As part of the post-restoration assessments, adult lake sturgeon were documented spawning on these reefs one year after completion and eggs and larvae have been collected, but accurate estimates of spawning adults and their origins have not yet been obtained. A third reef, Maslankas, in the north channel of the St. Clair River was inadvertently created over 100 years ago when a barge dumped coal cinders into the water (Fig 4). Although this site is considered a historic spawning reef, it is an artificial reef and the numbers and origins of spawning adults have not been estimated.

Lake sturgeon are known for homing capabilities as well as their migratory habits, and as such, the origins of the spawning population for the new reefs are unknown. Tagging studies in Lake Michigan, Lake Winnebago, and Lake Superior have shown these fish capable of migrating more than 300 kilometers (Prigel and Wirth 1971, Hay-Chmielewski 1987, Lyons and Kempinger 1992, Auer 1999). Studies in the HEC have shown a preference for a home range residence even when movement is not blocked by barriers (Thomas and Haas 2002, Caswell 2004, Boase et al. 2011). A large proportion of lake sturgeon have been shown to display natal fidelity and return to the same spawning site each spawning event (Prigel and Wirth 1971, Prigel and Wirth 1977, Lyons and Kempinger 1992, Auer 1999, Caswell 2004, Boase et al. 2011). Lake sturgeon are likely cued into chemical conditions of a stream or river; once in that area, the fish will look for appropriate spawning areas within that region (J. Chiotti, personal communication). New telemetry data is also confirming this tendency to stay within a home range (Boase et al. in press).

To verify the success and efficacy of the artificial reefs, genetics were used to determine the source population of adult lake sturgeon spawning on the reefs. When new populations are discovered, scientists and managers need to know who colonized a new area, especially in the case of a threatened species. Knowing the source of a new population helps managers to determine if smaller populations are reduced by the presence of a new reef, ensures there is enough genetic variability to allow the new 
population to thrive long term, and can determine if there are unknown natural reefs in the vicinity that have not been sampled. In order for the Great Lakes region to support lake sturgeon, there needs to be some habitat already available to them. Increasing the amount of spawning habitat should assist in increasing population sizes when reproductive habitat is the limiting factor (Manny et al. 2005, Daugherty et al. 2008, Randall 2008, Manny 2010, Kerr et al. 2011).

A method using genetics to determine origins of populations is through assignment testing, which takes genotypes and allele frequencies from samples across multiple loci to categorize them into groups based on similarity. Assignment tests can be performed through measuring three different genetic characteristics: allele frequency, genetic distance, and Bayesian statistics. Because loci are highly variable, proportions of shared alleles among samples represent degrees of relatedness. Expected allele frequencies can be obtained from potential source populations. An individual sample will have an expected allele frequency; that sample will assign to the source where the expected frequency is the highest.

Since genetic drift is responsible for genetic changes over short periods of time, changes in allele frequencies can be used to detect genetic distances between samples (Nei 1972). Measuring genetic distance shows how closely related individuals are. The smaller the distance, the more similar the individuals' genes are; for example populations with alleles in the same frequencies are genetically the same. There are several measures of distance, including Cavalli-Sforza (1967) where changes arise from genetic drift, Nei's standard genetic distance (1972) measuring the number of changes per locus where allele changes arise from either mutation or genetic drift, and Reynolds, Weir, and Cockerham (1983) which also assumes changes arise from genetic drift.

Assignment with Bayesian analysis considers a known population to estimate the probability of unknown individuals belonging to an established group. One approach is by clustering individuals together by increasing Hardy Weinberg equilibrium (HWE) and decreasing linkage disequilibrium. HWE is an ideal situation where allele frequencies remain constant between generations, and increasing this clusters individuals together with similar allele frequencies. Decreasing linkage disequilibrium clusters individuals together whose alleles are in their expected occurrence. This process is iterative, so as similarities are found, they are used to create new probabilities.

There were several assignment testing software applications utilized. STRUCTURE (Pritchard et al 2000) is a full Bayesian clustering software program that uses genotypes and allele frequencies to assign samples to likely $k$ populations. This program assumes admixture, all populations are in HardyWeinberg equilibrium (HWE), and that markers are unlinked and in complete linkage equilibrium to find groupings that are not in disequilibrium. STRUCTURE clusters populations together by increasing HWE and decreasing linkage disequilibrium. The weakness in STRUCTURE is that it is based on the Wahlund effect (Wahlund 1928), which is a decrease in heterozygosity caused by subpopulation structuring . However, a population could be out of HWE because of other reasons, such as the existence of family structure in which STRUCTURE will cluster by family structure rather than population. When there is family structure within a population, the genotypes and allele frequencies are most similar between the families. Therefore the program will separate out more populations than truly exist. The program runs with a selected number of Markov chain Monte Carlo (MCMC) repeats and burn-in and lengths: repeated algorithms that do not retain a memory of the prior algorithms that estimate a distribution to compute a mean. STRUCTURE HARVESTER (Earl and VanHoldt 2011) is a web-based application, using the STRUCTURE result file, that identifies the most likely number of populations $(k)$, using the Evanno 
method (Evanno et al. 2005) to calculate the change in $k$ (delta $k$ ): the log probability rate of change between every tested value of $k$.

Another assignment method, FLOCK (Duchesne and Turgeon 2009), groups samples according to their ancestral differentiation lines into clusters $k$ through a positive feedback mechanism of repeated reallocation with subsamples which attract each other by genotypic similarities. The re-allocations are done using maximum likelihoods and the leave-one-out procedure and can be applied to any potential value of $k$ that the user predefines. FLOCK outputs log likelihoods, LLOD scores across groupings which then must be used to validate the correct $\mathrm{K}$ outside of the program.

ONCOR (Kalinowski et al. 2007) is an assignment program that performs a mixture analysis of the sampled populations and compares to the potential source populations. Using conditional maximum likelihood (Millar 1987), iterations are repeated until the change between iterations becomes stable. ONCOR is validated by using the source population allele information to verify it can correctly assign the individuals back to its known population. The program offers several validation methods, including a $100 \%$ simulation in which all populations are assumed to be from the same population and proportions of each population, with confidence intervals, are assigned to a source. Additional validation is provided by a leave-one-out test and by simulating realistic fisheries proportions to estimate the probability that individuals occur in the baseline populations (Anderson et al 2007). The leave-one-out test removes one individual at a time to estimate its origin; once they have all been estimated, the program calculates the percentage of correctly assigned individuals. The realistic fisheries option is similar to the $100 \%$ simulation, however fisheries do not tend to be from a single source or evenly distributed between sources. The realistic fisheries option enables a user to predict possible proportions while the program estimates the probability of occurring in those populations. ONCOR supplies two methods of assigning unknown samples: one by assigning each individual to a source, and a mixture analysis in which the proportions of source populations are provided for the unknown samples when analyzed as a group. A mixed stock analysis loses individual resolution; it instead looks at what proportion of the group assigns to a particular source.

GENECLASS2 (Piry et al. 2004) is a highly conservative software package that assigns individuals of an unknown origin to a possible source population; a partial Bayesian assignment analysis calculates exclusion probabilities. This program allows a choice between two Bayesian methods described in Rannala and Mountain (1997) and Baudouin and Lebrun (2001). There are three algorithms that can be used to calculate assignment probabilities using MCMC resampling: Paetkau et al. (2004), Cornuet et al. (1999), or Rannala and Mountain (1997). GENECLASS2 is validated by using the source population allele information to verify it can correctly assign the individuals back to its known population.

The objective of this study was to assign larval lake sturgeon recovered from three artificial reefs in the $\mathrm{HEC}$ to an adult source population in the Great Lakes. Four assignment testing analyses were used to determine the origins of the parental population of larval lake sturgeon on three artificial reefs. The lake sturgeon population in the HEC is considered large (Hayes and Caroffino 2012) and genetically diverse (Welsh et al. 2008). As there is evidence towards a large majority of residential fish, it is most likely that any offspring found in the region are the result of spawning individuals residing in the HEC. If this is the case, it is unlikely that smaller remnant populations would experience further declines due to migration to these new reefs. This would also support continued protections of lake sturgeon spawning areas and the construction of additional reefs within the HEC. 


\section{METHODS}

Sample collection: US Geological Survey Great Lakes Science Center (USGS GLSC) personnel laid egg mats on top of three artificial reefs during the spawning seasons of 2009-2012: Fighting Island, Maslankas, and Middle Channel as described in Roseman et al. (2011) (eggs were not collected in 2010 or 2011 at Fighting Island due to unseasonably high water temperatures at the time of sampling). Mats were brought up weekly, weather permitting, and carefully checked for eggs which were then transferred into containers to rear in the lab at the USGS GLSC. Prior to placement in the laboratory system, eggs were treated with Ovadine followed by hydrogen peroxide after initial hardening to prevent fungal contamination. Once the eggs hatched, the larvae were preserved in $95 \%$ ethanol. Forty larvae hatched from the Middle Channel reef, 225 from Maslankas reef, and 183 from Fighting Island reef.

Laboratory procedures: Genomic DNA was extracted from lake sturgeon larvae using the Qiagen Gentra Puregene kit following the manufacturer's mouse tail protocol. DNA was quantified using a spectrophotometer (ThermoScientific nanodrop) and were diluted to a concentration of $10 \mathrm{ng} / \mu \mathrm{l}$. Twelve microsatellite loci were analyzed (AfuG9, AfuG56, AfuG63, AfuG74, AfuG112, AfuG160, AfuG195, AfuG204- Welsh et al. 2003, Afu68, Afu68b- May et al. 1997, Aox27- King et al. 2001, and Spl120McQuown et al. 2000). The sequences for each primer are provided in Table 1.

Eleven microsatellite loci were amplified from the extracted DNA using either the MJ Research PTC100, the Eppendorf Mastercycler Nexus, or the BioRad C1000 touch thermocyclers. Afu68b (McQuown et al. 2002) was not amplified separately, but is displayed through secondary amplification because it shares the reverse primer of Afu68. All loci were amplified through PCR with Promega reagents in 10 $\mu$ l reactions: $2 \mu \mathrm{l} 5 \mathrm{x}$ Buffer, $0.6 \mu \mathrm{l}$ of $\mathrm{MgCl} 2,0.2 \mu \mathrm{l}$ dNTP mix, $0.05 \mu \mathrm{l}$ GoTaq polymerase, and either $2.95 \mu \mathrm{l}$ or $4.95 \mu \mathrm{l}$ of nuclease-free water. AfuG9 and Spl120 were amplified using 40ng of DNA requiring less water; the rest were amplified using 20ng of DNA. Tables 2 and 3 list PCR programs and capillary information for each locus, including analysis parameters. Three PCR programs were required to run the 11 loci, due to secondary amplification by AfuG56 and Spl120 and to inconsistency in AfuG9. Loci were combined each with a different fluorescent dye into groups of four to visualize through capillary electrophoresis on the Beckman Coulter GenomeLab GeXP Genetic Analysis System.

Genetic analysis: Of the number of larvae hatched, 40,167, and 176 individuals were analyzed from Middle Channel $(2012)$, Maslankas $(2011,2012)$ and Fighting Island $(2009,2012)$ reefs, respectively (described in Chapter 1). The samples from each reef were then compared to potential source populations. Previously identified Upper Great Lakes sturgeon populations (Welsh et al 2008) were considered potential parental sources of the larvae on each artificial reef. The populations below Niagara Falls were excluded as sturgeon have not been identified migrating upstream through the Welland Canal, and Niagara Falls is a physical barrier to upstream movement (Daniels 2001). The 22 Upper Great Lakes sites are pictured in Figure 5. Analysis was performed two ways: comparing samples collected from the artificial reefs to each of the 22 potential source sites individually, and comparing the artificial reef samples to regions of sites grouped into genetically distinct clusters. This was done to limit assignment to multiple sites due to the low genetic differentiation between some of the Great Lakes sturgeon populations (Welsh et al. 2008). Northern Superior included the Kaministiqua, Black Sturgeon, and Pic rivers. Western Michigan contained the Menominee, Wolf, Peshtigo, Oconto, and Fox rivers, while Eastern Michigan included the Kalamazoo, Manistee, and Muskegon rivers. Nipissing consisted of the East Nipissing and West Nipissing populations in Lake Nipissing; the North Channel in Lake Huron 
consisted of the Spanish and Mississaugi rivers. There were three remaining regions consisting of genetically similar pairs: the Detroit and St. Clair rivers, the Bad and the White rivers (in Lake Superior), and the Sturgeon and Goulais rivers (in Lake Superior).

STRUCTURE was used initially to determine if there was differentiation between the populations and to see if the artificial reef populations had originated from any of the potential sources. 22 potential source populations were used to compare with the three sample reef sites. The potential source populations were also grouped by region of genetic similarity and compared with the three sample reef sites. All three reefs were analyzed with a burn-in length of 100,000 , followed by $100,000 \mathrm{MCMC}$ length replications, 10 iterations, and no priors. The STRUCTURE result file was uploaded to the site STRUCTURE HARVESTER, which calculated the likely $k$ values for each of the three sample reefs when compared to the potential source populations. This $k$ value was visualized in STRUCTURE to create bar graphs depicting the population clusters. The artificial reef was the first group in all three analyses, followed by the potential source populations. Each population that had a dissimilar pattern to the artificial reef was removed from analysis. The remaining populations were then reanalyzed with the artificial reefs. This was repeated until the pattern of a potential source population matched, or was similar to, the artificial reef.

A range of $k$ values was input into FLOCK of two to six. The remaining analysis selections were kept at the default options: random initial partition mode, 20 iterations, 50 runs, and the minimal log likelihood difference to allocate specimens to reference groups was set equal to zero. Once analysis was complete, a plateau file was automatically created by FLOCK displaying the number of populations most likely. This is determined by sequences of plateau lengths of greater than six. The file with the $k$ value determined by the plateau file displayed sample allocations to clusters were then based upon the most likely $k$ value. The three artificial reefs were compared together against the 22 potential source populations and the 8 potential source regions. Any cluster not containing an artificial reef was removed from further analysis. The cluster containing the artificial reefs was reanalyzed with the remaining potential source populations.

In ONCOR, the reference populations were first used to validate the program's ability to correctly assign populations back to their known origin. Under the mixture analysis option, both the $100 \%$ simulations as well as the realistic fishery simulation were performed. The individual assignment option was also performed with the reference populations using both the leave-one-out test and the realistic fishery simulation. Each artificial reef was analyzed with the reference populations and the reference regions in ONCOR using the mixture analysis with mixture proportions and bootstrap confidence intervals option and the individual assignment option.

In Geneclass2, each Bayesian method was combined with all three probability methods and were used to assign probabilities that samples belonged to an original population with 100,000 simulated individuals. Validation of this analysis entails assigning individuals from the reference sites to see if the program can correctly assign those individuals to their known populations with high confidence. A threshold of $80 \%$ likelihood ratio of assignment was set. Any individual scoring less than this threshold was considered unassigned. All individuals scoring above $80 \%$ were considered assigned. Of those, individuals correctly assigned to the region it came from were included into a percent accuracy of assignment. Genotypic probabilities were also calculated using the Rannala and Mountain (1997) method. The bootstrap option was selected which uses replacement to resample individuals in the unknown population. 


\section{RESULTS}

All Lake Superior populations, both during regional or by site analysis in STRUCTURE, were clustered separately from the artificial reefs in the first run, indicated by differing patterns in the STRUCTURE bar plots. These dissimilar populations were removed from analysis and the remaining populations were reanalyzed. Lake Michigan populations as well as the North Channel and Nipissing populations, both by region and by site, were removed during subsequent runs. STRUCTURE HARVESTER results indicated $\mathrm{k}=$ 2 for each STRUCTURE analysis. The Detroit and St. Clair rivers were indicated as the likely source for the larvae from Fighting Island, Maslankas, and Middle Channel artificial reefs. Fighting Island had similar patterns in the bar plot to the Detroit and St. Clair rivers with the North Channel and Lake Nipissing sites remaining in analysis until the final run (Fig 5 and 6). Maslankas reef had similar patterns to the Detroit and St. Clair rivers. Eastern Lake Michigan populations remained in analysis until the final run and had similar visual patterns to the Maslankas reef, the Detroit River, and the St. Clair River populations (Fig 7 and 8). The Middle Channel larvae appeared most similar to the Detroit- St. Clair populations throughout the analysis, though the signals were not an exact match (Fig 9 and 10).

Prior to running FLOCK, the Goulais population had to be removed from the initial analysis because of its inability to cluster to any particular group. The initial run resulted in a $k=2$, clustering the Black Sturgeon with the White, Bad, Kaministiqua, Pic and Sturgeon river populations; these sites are all in Lake Superior. The 18 remaining sites were again clustered after removing the North Channel, the Nipissing, and Eastern Michigan sites. This resulted with $k=2$ clustering the three artificial reefs with the St. Clair and Detroit River populations (Fig 11).

Similar to analysis by population, during the analysis by region, FLOCK separated the regions into two clusters. The first cluster contained the Bad-White with Northern Superior with $k=2$ after GoulaisSturgeon was removed; again these sites are all in Lake Superior. Two additional regions, Eastern Michigan and the North Channel, were removed due to inability to attract to any particular cluster. Western Michigan was clustered alone and all three artificial reefs were again clustered with the Detroit-St. Clair region and Nipissing with $k=2$. The final analysis again resulted in $k=2$ grouping Nipissing alone and the artificial reefs with the Detroit and St. Clair populations (Fig 12).

Through ONCOR, simulations revealed $90 \%$ accuracy of correct assignment $(95 \% \mathrm{Cl}: 79,100)$ for the baseline populations back to their known origin when analyzed by region. When analyzed by site, correct assignment was less accurate and more variable ranging from $13 \%$ to $99 \%(95 \% \mathrm{Cl}: 1,100)$ of baseline populations back to their known origin. Mixture analysis of the larval samples by site provided assignment proportions to either the Detroit or St. Clair river at $87 \%, 87 \%$ and $93 \%$ for Fighting Island, Maslankas and Middle Channel respectively. When analyzed by region, the assignment to the Detroit-St. Clair region was the highest for all three artificial reefs resulting in assignments of $88 \%, 93 \%$ and $100 \%$ for Fighting Island, Maslankas and Middle Channel Reefs. Individual assignment by site resulted in low accuracy, the ability to assign to a source population greater than $80 \%$. Of the Fighting Island reef larvae, $46 \%$ were able to be assigned, Maslankas larvae, $44 \%$, and Middle Channel, $43 \%$ were able to be assigned. Of those, $94 \%, 96 \%$, and $88 \%$ of Fighting Island, Maslankas, and Middle Channel larvae assigned to the Detroit or the St. Clair River. The remaining individuals assigned to the Spanish, West Nipissing, Mississaugi, and Menominee sites. Accuracies were much higher when the larvae were individually assigned by region. Fighting Island, Maslankas, and Middle Channel had accuracies of $88 \%$, $93 \%$, and $100 \%$ with $95 \%, 98 \%$, and $100 \%$ of those individuals assigning to the Detroit-St. Clair region. 
The remaining individuals assigned to the North Channel, the Sturgeon-Goulais, Lake Nipissing, or Northern Superior regions. (Tables 4 and 5).

Geneclass 2 validation of the potential source sites resulted in percentage of individuals correctly assigned of $34 \%, 46 \%$, and $47 \%$ when analyzed using the Rannala and Mountain (1997) analysis with Paetkau et al.(2004), Rannala and Mountain (1997), and Cornuet et al.(1999) algorithms for probability, respectively. The correct assignment using Baudouin and Lebrun (2001) Bayesian analysis with each algorithm was $26 \%, 44.5 \%$, and $45 \%$, respectively. The analysis was repeated with the 8 potential source regions and resulted in correct assignment of $47 \%, 69 \%$, and $69 \%$ with Rannala and Mountain (1997) analysis and 44\%,67\%, and 67\% using Baudouin and Lebrun (2001) analysis.

The values above provided by the software were lower than an $80 \%$ cut off value, so the reference regions were then analyzed using only the Bayesian analyses: using only the Rannala and Mountain method and then using only the Baudouin and LeBrun method. The Bad-White region had an assignment of $78 \%$ and an accuracy of $96 \%$ using both partial Bayesian methods. In the remaining regions, between $12 \%$ to $48 \%$ of the individuals were able to be assigned using the Rannala and Mountain method and the remaining individuals not excluded due to the $80 \%$ cutoff value were accurately assigned to their correct region between $70 \%$ and $97 \%$ (Table 6). Using the Baudouin and LeBrun method, $8 \%$ to $45 \%$ of the individuals could be assigned. Of those, $63 \%$ to $100 \%$ were correctly assigned to their region (Table 7). To determine which analysis had higher assignment and accuracy, the average percent assignment and percent accuracy were calculated to serve as a comparison between the two methods. The Rannala and Mountain method was able to assign an average of $37 \%$ of the individuals with an average $83 \%$ accuracy while the Baudouin and LeBrun method was able to assign an average of $31 \%$ of the individuals with an average of $82 \%$ accuracy.

The artificial reefs were analyzed using only the Rannala and Mountain analysis by region (Table 8). The percentage of Fighting Island, Maslankas, and Middle Channel larvae that could be assigned (meeting the $80 \%$ likelihood ratio) was $16 \%, 28 \%$, and $8 \%$. Of the individuals that were able to be assigned, percent assignments to the Detroit-St. Clair region were the highest: $65 \%, 74 \%$, and $100 \%$. The remaining $35 \%$ of Fighting Island individuals were assigned to the Bad and White rivers $(n=1)$, the North Channel $(n=3)$, Lake Nipissing $(n=1)$, and Eastern Michigan rivers $(n=1)$. The remaining $26 \%$ of individuals from Maslankas were assigned to populations in Lake Superior $(n=7)$, the North Channel $(n=2)$, and Lake Nipissing $(n=3)$.

\section{DISCUSSION}

The Detroit and St. Clair river populations were the most likely source of spawning adults contributing to the larvae collected from Fighting Island, Maslankas, and Middle Channel artificial reefs. This supports the hypothesis that local populations are utilizing these reefs. These results are in agreement with other studies showing that lake sturgeon exhibit spawning and residential homing behaviors. Auer (1996) showed that lake sturgeon are very capable of migrating long distances, however most do not take advantage of this capability. In tagging studies, the majority of lake sturgeon have been found to stay in local areas and return to preferred spawning grounds within a local region (Lyons and Kempinger 1992, Auer 1996, Boase et al. 2011, Forsythe et al. 2012). While there has been evidence of straying from home regions, there have been several genetic studies that show a majority of lake sturgeon either stay within a home range or migrate out and back to their natal areas (DeHaan et al. 2006, Welsh et al. 2008). Bott (2006) and Homola et al. $(2010,2012)$ found high amounts of natal homing and little 
movement from the home range by studying gene flow of wild lake sturgeon in Lake Superior and Lake Michigan. These behaviors are not limited to lake sturgeon as low levels of movement away from a home range has been verified in other species that exhibit natal fidelity such as American shad, Alosa sapidissima, (Hendricks et al. 2002) and pink salmon, Oncorhynchus gorbuscha, (Morensen et al. 2002).

The stringency of GeneClass 2 was likely too high to differentiate between the genetically similar Great Lakes sturgeon populations. Welsh et al. (2008) showed that lake sturgeon populations in the Great Lakes have little differentiation derived by $F_{S T}$ values and by low numbers of alleles per locus. $F_{S T}$ is a standardized (by allele frequencies) measure of genetic differentiation between populations. This value can range from zero to 1 being complete differentiation shown by having fixed, private alleles in separate populations (Wright 1943). $\mathrm{F}_{\mathrm{ST}}$ is affected by genetic drift, migration, and geographic distance versus population size (Wright 1943, Whitlock 2011). Berry et al. (2004) established a clear relationship between $F_{S T}$ values and the ability to assign individuals to their source correctly wherein the $F_{S T}$ values were as high as 0.11 and were not lower than 0.04 . However, the $F_{S T}$ values for the Great Lakes sturgeon populations provided by Welsh et al. (2008) range from 0.17 as the most differentiated sites, such as the Menominee River compared to the White River (sites in the most recent of the Great Lakes created after the recession of the Laurentian Ice Sheet), to 0.02 as the most undifferentiated sites, such as the Detroit River compared to East Lake Nipissing. Though an $\mathrm{F}_{\mathrm{ST}}$ value above 0.15 is considered a large amount of differentiation (Wright 1978), most of the $F_{S T}$ values are below 0.15 signifying small to moderate amounts of differentiation in the Great Lakes.

Lake sturgeon microsatellite loci have a range of 2-11 alleles across the 12 loci analyzed with an average of 5.5 alleles per locus. In other species, the number of alleles is much higher, such as Atlantic sturgeon, Acipenser oxyrinchus oxyrinchus, with up to 20 alleles per locus (King et al. 2001), over 20 alleles per locus in Atlantic salmon, Salmo salar, (Oystein et al. 2006), and 70 alleles per locus in human ABO blood type (Yip 2002), and the average number of alleles per locus is higher than that of lake sturgeon (Chakraborty et al. 1979, King et al. 2001, Rueda et al. 2011). Kalinowski et al. (2004) determined that in populations with very low $\mathrm{F}_{\mathrm{ST}}$ values and low sample numbers, a significantly high number of alleles is required for certain analyses.

STRUCTURE, FLOCK and ONCOR had high agreement in placing the sampled larvae with the Detroit River and St. Clair River adult populations. These results agree with GLATOS's preliminary telemetry data showing that a majority of adult lake sturgeon in the HEC stay within a home range rather than migrating long distances. Each of these programs is in agreement between site and regional analysis as well.

In FLOCK and STRUCTURE, Lake Nipissing and the North Channel of Lake Huron were the last sites/regions to be removed from the analysis of Fighting Island and the Middle Channel (recently built) while the Eastern Michigan sites/region were the last to be removed from the Maslankas ( 150 years old) analysis. The North Channel connects Lake Superior to Lake Huron, separated to the north of Lake Huron by several islands. Lake Nipissing is a very shallow, large lake and is connected to the Georgian Bay, an 80 kilometer wide bay of Lake Huron, by the meandering French River which is 109 kilometers long with scattered islands. There is a 100 year old French River Dam Complex that inhibits free movement between the lakes, although that length of time is approximately equal to only four generations of lake sturgeon. There are three possible explanations for the genetic similarities of these sites to the larvae on the three reefs: error/sample size, the glacial recolonization history, and lake sturgeon movement. 
Assignment testing has several potential sources of error. A type A error entails incorrectly excluding a parent population which would result in under assignment. False assignment of samples results from including only populations that are not the source. Since there is general consensus between several software programs, it is not likely that there is false assignment, but there is a possibility of unsampled source populations in the St. Clair River. It was determined that due to location and age of eggs found upstream of the artificial reef, there are likely other natural spawning sites in the St. Clair River between Middle Channel and the Blue Water Bridge in Port Huron (Bouckaert 2013). Bennion and Manny (in press) modeled that same area as ideal spawning habitat in which suitable substrates already exist supporting large numbers of spawning lake sturgeon (Boase and Hill 2002). Incorrectly scoring alleles is not a likely source of error since the allelic patterns of the artificial reef larvae are similar to the patterns discovered by Welsh et al. (2008) and there were no rare or uncommon alleles scored. The final source of error could be insufficient sampling. Lower accuracy of assignment for the Middle Channel larvae is most likely due to an insufficient sample size. There is no consensus on the number of loci and samples required to complete an accurate assignment test, according to Berry et al. (2004), there also must be a large enough sample size and a sufficient number of loci tested in order to complete assignment testing. Large population sizes $(>100)$ were not required when utilizing highly polymorphic loci (Kalinowski 2005). In various studies, 8 loci and a sample size of 35 to as low as 18 have been used successfully in assignment testing (Berry et al. 2004, DeHaan et al. 2006), although the minimum numbers are dependent on high variability of markers used. Even with 12 loci, a sample size of 40 is small, and some software packages note that there is lower accuracy in small sample sizes. To correct any analysis error due to small sample size, it is recommended to analyze more samples from the Middle Channel reef.

Another possible theory for the genetic relationships of multiple sites with the HEC reefs is the recolonization of sturgeon to the Great Lakes after the glaciers receded. The current form and water flow in the Great Lakes is only about 3,000 years old, when the water levels and land levels stabilized without the heavy ice load. There were several forms and drainages of the Great Lakes during the recession of the Laurentian ice sheet (Teller 1995, Clark et al. 2007, Breckenridge and Johnson 2009). Lake Sturgeon recolonization to Lake Huron and Lake Ontario would have started at western Lake Erie. Fish would have been forced northward or eastward - during the middle of the recession, western Lake Erie did not hold any water due to the height of land mass (Clark et al. 2007). About 7,000 years ago, the Upper Great Lakes were one unified lake which included Lake Nipissing. Though this large lake had three outlets, the St. Clair-Detroit rivers, the Mississippi-Illinois rivers, and the Ottawa-St. Lawrence rivers, the flow of Lake Huron most often moved towards the Ottawa-St. Lawrence rivers until about 5,000 years ago (Lewis at al. 1994). Because the timing of recession and the drainages available to the areas, the glacial history of the Great Lakes does not seem to explain the genetic similarity of the larvae to populations in Lake Nipissing, the North Channel, or Eastern Michigan.

One might expect genetic similarity to correspond with geographic distance, however, it appears that geographic distance alone is not an indicator of genetic similarity. Fish movement and behavior likely play important roles in genetic similarity between separate populations. The fact that these sites were the last to be removed as potential source populations may also indicate that historical movement patterns are influential, because even an occasional influx of migrants would be enough for genetic studies to show parental or ancestral origins. It is hypothesized that lake sturgeon move along shorelines, or shallow areas, and do not cross deeper lake basins (Boase et al. 2011).

Management Implications As a result of the genetic similarity of the lake sturgeon in this study to spawning populations in the Detroit and St. Clair rivers, the HEC populations can be treated as a single management unit (Taylor and Lee 1995, Moritz 1994) where population dynamics are controlled locally. 
With strong agreement from all analyses, the Detroit and St. Clair rivers are the most likely parental population of the larvae from Fighting Island reef, Maslankas reef, and the Middle Channel reef. Further sampling should be conducted to ensure sampling of all spawning populations in the HEC and to increase the sample size for the Middle Channel reef. The results of this analysis give assurance to managers and scientists of the Great Lakes that more fragile populations are not in danger of declining due to the addition of suitable spawning habitat in the HEC. This study also supplies additional evidence that many members of the population spawn locally. This may also have implications towards increasing artificial spawning habitats in other areas presumed to have lake sturgeon. 


\section{Literature Cited}

Anderson, E.C., Waples, R.S., Kalinowski, S.T., 2008. An improved method for estimating the accuracy of genetic stock identification. Canadian Journal of Fisheries and Aquatic Sciences. 65: 1475-1486.

Auer, N.A. , 1996, Importance of habitat and migration to sturgeons with emphasis on lake sturgeon Canadian Journal of Fisheries and Aquatic Science. 53(Suppl. 1): 152-160.

Auer, N.A. 1996. Response of spawning lake sturgeon to change in hydroelectric facility operation. Transactions of the American Fisheries Society. 125: 66-77.

Auer, N.A., 1999, Population Characteristics and Movements of Lake Sturgeon in the Sturgeon River and Lake Superior. Journal of Great Lakes Resources. 25(2): 282-293.

Bennion, D.H., Manny, B.A., A model to locate potential areas for lake sturgeon habitat construction in the St. Clair-Detroit River system. Journal of Great Lakes Research. In press.

Berry, O., Tocher, M.D., Sarre, S.D., 2004, Can assignment measure dispersal?, Molecular Ecology. 13: 551-561.

Boase, J.C., Hill, T., 2002. Final report for lake sturgeon spawning in St. Clair River near Port Huron, Michigan. National Fish and Wildlife Foundation Project No. 2001-0058-008.

Boase, J.C., Diana, J.S., Thomas, M.V., Chiotti, J.A., 2011. Movements and distribution of adult lake sturgeon from their spawning site in the St. Clair River, Michigan. Journal Applied Ichthyology. 27: 5865.

Boecklen, W.J., Howard, D.J., 1997. Genetic analysis of hybrid zones: numbers of markers and power of resolution. Ecology. 78: 2611-2616.

Bott, K.J., 2006. Genetic analysis of dispersal, harvest mortality, and recruitment for remnant populations of lake sturgeon, Acipenser fulvescens, in open water and riverine habitats of Lake Michigan. M.Sc. thesis, Michigan State University, East Lansing, MI.

Bouckaert, E.K., 2013. Verifying success of artificial reefs in the Huron-Erie Corridor for lake sturgeon. Michigan Technological University. 72pp.

Breckenridge, A., Johnson, T.C., 2009. Paleohydrology of the upper Laurentian Great Lakes from the late glacial to the early Holocen. Quaternary Research. 71: 397-408.

Caswell, N.M., Peterson, D.L., Manny, B.A., Kennedy, G.W., 2004. Spawning by lake sturgeon (Acipenser fulvescens) in the Detroit River. Journal of Applied Ichthyology. 20: 1-6.

Cavalli-Sforza, L.L., Edwards, A.W.F., 1967. Phylogenetic Analysis -Models and Estimation Procedures. The American Journal of Human Genetics. 19:3 Part I 
Chakraborty, R., Fuerst, P.A., Nei, M., 1979. Statistical studies on protein polymorphism in natural populations. III. Distribution of allele frequencies and the number of alleles per locus. Genetics. 94:1039-1063.

Clark, J.A., Zylstra, D.J., Befus, K.M., 2007. Effects of Great Lakes water loading on glacial isostatic adjustment and lake history. Journal of Great Lakes Research. 33(3): 627-641.

Daniels, R. A. 2001. Untested assumptions: the role of canals in the dispersal of sea lamprey, alewife, and other fishes in the eastern United States. Environmental Biology of Fishes. 60: 309-329.

Daugherty, D. J.; Sutton, T. M.; Elliot, R. F., 2008: Suitability modeling of lake sturgeon habitat in five northern Lake Michigan tributaries: implications of population rehabilitation. Restoration Ecology 17: 245-257.

DeHaan, P.W., Libants, S.V., 2006. Genetic population structure of remnant lake sturgeon populations the Upper Great Lakes Basin. Transactions of the American Fisheries Society. 135: 1478-1492.

Duchesne, P., Turgeon, J., 2009. FLOCK: A method for quick mapping of admixture without source samples. Molecular Ecology Resources. 9: 1333-1344.

Duchesne, P., Turgeon, J., 2012. FLOCK provides reliable solutions to the "number of populations" prolem. Journal of Heredity. advance access. 1-10.

Earl, D.A., VonHoldt, B.M., 2012. STRUCTURE HARVESTER: a website and program for visualizing STRUCTURE output and implementing the Evanno method. Conservation Genetics Resources. 4(2): 359361.

Evanno, G., Regnaut, S., Goudet, J., 2005. Detecting the number of clusters of individuals using the software STRUCTURE: a simulation study, Molecular Ecology. 14: 2611-2620.

Falush, Stephens and Pritchard (2003) Inference of Population Structure Using Multilocus Genotype Data: Linked Loci and Correlated Allele Frequencies. Genetics. 164(4): 1567-1587.

Falush, Stephens and Pritchard (2007) Inference of population structure using multilocus genotype data: dominant markers and null alleles Molecular Ecology Notes. 7: 574-578.

Forsythe, P.S., Scribner, K.T., Crossman, J.A., Ragavendran, A., Davis, C., Baker, E.A. , Smith, K.K., 2012. Environmental and lunar cues are predictive of timing of river entry and spawning site arrival in lake sturgeon. Journal of Fish Biology. 81(1): 35-53.

Hay-Chmielewski, E.M., 1987. Habitat preferences and movement patterns of the lake sturgeon (Acipenser fulvescens) in Black Lake, Michigan. Michigan Department of Natural Resources, Fishery Division. Fisheries Research Report No. 1949.

Hendricks, M.L., Hoopes ,R.L., Arnold, D.A., 2002. Homing of Hatchery reared American Shad to the Lehigh River, a tributary to the Delaware River. North American Journal of Fisheries Management 22: 243-248. 
Homola, J.J., Scribner, K.T., Baker, E.A., Auer. N.A., 2010, Genetic Assessment Of Straying Rates Of Wild And Hatchery Reared Lake Sturgeon (Acipenser fulvescens) In Lake Superior Tributaries. Journal of Great Lakes Research 36: 798-802.

Homola, J.J., Scribner, K.T., Elliott, R.F., Donofrio, M.C., Kanefsky, J. , Smith, K.M., 2012. Genetic estimates of assymetrical natural straying rates are not predictive of historical migration among Lake Michigan lake sturgeon spawning populations. Transactions American Fisheries Society. 141(5): 13741388.

Hubisz, M.J., Falush, D., Stephens, M., Pritchard, J.K., 2009. Inferring weak population structure with the assistance of sample group information Molecular Ecology Resources. 9: 1322-1332.

Kalinowski, S.T., 2002. How many alleles per locus should be used to estimate genetic distances? Heredity. 88: 62-65.

Kalinowski, S.T., 2004. Genetic polymorphism and mixed-stock fisheries analysis. Canadian Journal of Fisheries and Aquatic Sciences. 61: 1075-1082.

Kalinowski, S.T., 2005. Do polymorphic loci require large sample sizes to estimate genetic distances? Heredity. 94: 33-36.

Kalinowski, S.T., Manlove, K. R., Taper, M. L., 2007. ONCOR: A computer program for genetic stock identification.

Kerr, S. J.; Davidson, M. J.; Funnel, E., 2010: A review of lake sturgeon habitat requirements and strategies to protect and enhance sturgeon habitat. Fisheries Policy Section, Biodiversity Branch. Ontario Ministry of Natural Resources, Peterborough, ON.58 pp + appendices.

Lewis, M.C.F., Moore Jr. T.C., Rea, D.K., Dettman, D.L., Smith, A.M., Mayer, L.A., 1994. Lakes of the Huron basin: their record of runoff from the Laurentide Ice Sheet. Quaternary Research. 13: 891-922.

Lyons, J., and Kempinger, J.J. 1992. Movements of adult lake sturgeon in the Lake Winnebago system. Wisconsin Department of Natural Resources. Resource Publication Number RS-156-92.

Manny, B.A., Read, J., Denison, D., Reider, R., Kennedy, G.W., Caswell, N., Boase, J., McClain, J., 2005. Creation of lake sturgeon spawning habitat in the Detroit River. In: Eedy, R., Hartig, J., Bristol, C., Coulter, M., Mabee, T., Ciborowski, J. (Eds.), State of the Strait: Monitoring for Sound Management. Great Lakes Institute for Environ. Res., Occas. Pub. No. 4. Univ. of Windsor, Windsor, Ontario, pp. 98-100.

Manny,B.A., 2010. Ecological benefits of constructing fish spawning habitat in the Detroit River. In: Hartig, J.H., Zarull, M.A., Corkum, L.D., Green, N., Ellison, R., Cook, A., Norwood, G., Green, E. (Eds.), State of the Strait: Ecological Benefits of Habitat Modification. Great Lakes Institute for Environ. Res., Occasional. Pub. No. 6. University of Windsor, Ontario, Canada, pp. 5.51-5.56.

Maraldo, D. 1997. Recovery of lake sturgeon (Acipenser fulvescens) in Lake Nipissing, Ontario. Paper presented at the 59th Midwest Fish and Wildlife Conference. December 7-10, 1997. Milwaukee, Wisconsin. 
McQuown, E.C., Sloss, B.L., Sheehan, R.J., Rodzen, J., Tranah, G.J., May, B., 2000. Microsatellite analysis of genetic variation in sturgeon (Acipenseridae): new primer sequences for Scaphirynchus and Acipenser. Transactions of the American Fisheries Society. 129, 1380-1388.

McQuown, E.C.; Gall, G.A.E.; May, B., 2002. Characterization and inheritance of six microsatellite loci in lake sturgeon. Transactions of the American Fisheries Society. 131: 299-307.

Millar, R.B., 1987. Maximum likelihood estimation of mixed stock fishery composition. Canadian Journal of Fisheries and Aquatic Sciences. 44: 583-590.

Mohr, L., Mathers, A., Friday, M., and Drouin, R. 2007. Great Lakes Branch lake sturgeon status statement. Ontario Ministry of Natural Resources. Unpublished Manuscript. 13 p.

Moritz, C., 1994. Defining 'evolutionary significant units' for conservation. Trends in Ecology and Evolution. 9: 373-375.

Mortensen, D.G., Wertheimer, A.C., Maselko, J.M., Taylor, S.G., 2002. Survival and straying of Auke Creek, Alaska, pink salmon marked with coded wire tags and thermally induced otolith marks. Transactions of the American Fisheries Society. 131: 14-26.

Nei, M., 1972. Genetic distance between populations. American Naturalist. 106: 283-292.

Oystein, S., Wennevik, V., Glover, K.A., 2001. Evidence of temporal genetic change in wild Atlantic salmon, Salmo salar L., population affected by farm escapees. ICES Journal of Marine Science. 63: 12241233.

Piry, S., Alapetite, A., Cornuet, J. M., Paetkau, D., Baudouin, L., Estoup, A. 2004. GeneClass2: A Software for Genetic Assignment and First-Generation Migrant.

Pratt, T. C. 2008. Population status and threats of lake sturgeon in designatable unit 8 (Great Lakes/St. Lawrence River watershed). Department of Fisheries and Oceans. Sault Saint Marie, Ontario. 24 p.

Priegel, G.R., Wirth, T.L., 1971. The Lake Sturgeon: Its Life Hstory, Ecology and Management, Wisconsin Department of Natural Resources, Publication 240, Madison, WI.

Priegel, G.R., Wirth, T.L., 1977. The lake sturgeon: its life history, ecology, and management. Wisconsin Department of Natural Resources. Publication 4-3600 (77). 20pp.

Pritchard, J. K., Matthew Stephens and Peter Donnelly, 2000, Inference of Population Structure Using Multilocus Genotype Data. Genetics 155: 945-959.

Randall, R.G., 2008. Narrative description and quantification of the habitat requirements of lake sturgeon (Acipenser fulvescens) in the Great Lakes and upper St. Lawrence River. Research Document. Fisheries and Oceans Canada. Ottawa, Ontario.

Reynolds, J., Weir, B.S., Cockerham, C. C., 1983. Estimation of the coancestry coefficient: Basis for a short-term genetic distance. Genetics 105: 767-779. 
Roseman, E.F., Manny, B., Boase, J., Child, M., Kennedy, K., Craig, J., Soper, K., Drouin, R., 2011. Lake sturgeon response to a spawning reef constructed in the Detroit River. Journal of Applied Ichthyology. 27( Supplement 2): 66-76.

Rueda, E.C., Amavet, P., Brancolini, F., Sommer, J., Ortí, G., 2011. Isolation and characterization of eight polymorphic microsatellite markers for the migratory characiform fish, Salminus brasiliensis. Journal of Fish Biology. 79: 1370-1375.

Superior Pursuit: Facts About the Greatest Great Lake - Minnesota Sea Grant University of Minnesota. copyright 2013 Retrieved on 3/19/14.

Taylor, M., Lee, J., 1995. Distribution and abundance of Canadian polar bear populations: a management perspective. Arctic. 48: 147-154.

Teller, J., 1995. History and drainage of large ice-dammed lakes along the Laurentian Ice Sheet. Quaternary Research. 28: 83-92.

Thomas, M.V., Haas, R.C., 2002. Abundance, age structure, and spatial distribution of lake sturgeon (Acipenser fulvescens) in the St. Clair System. Journal of Applied Ichthyology. 18: 495-501.

Wahlund, S. 1928. Zusammensetzung von Populationen und Korrelationserscheinungen von Standpunkt der Vererbungslehre aus betrachtet. Hereditas. 11: 65-106. English translation in Pages 224-263 in K. M. Weiss, and P. A. Ballanoff, editors. Demographic genetics. Dowden, Hutchinson and Ross Inc, Stroudsburg, Pennsylvania, USA.

Welsh, A., Blumberg, M., and May, B., 2003, Identification of Microsatellite Loci in Lake Sturgeon, Acipenser fulvescens, and their Variability in Green Sturgeon, A. medirostris, Molecular Ecology Notes. 3: 47-55.

Welsh, A., Hill, T., Quinlan, H., Robinson, C., and May, B., 2008, Genetic Assessment of Lake Sturgeon Population Structure in the Laurentian Great Lakes, North American Journal of Fisheries Management 28: 572-591.

Welsh, A.B., Elliott, R.F., Scribner, K.T., Quinlan, H.R., Baker, E.A., Eggold, B.T., Holtgren, J.M., Krueger, C.C., May, B. Genetic guidelines for the stocking of lake sturgeon (Acipenser fulvescens) in the Great Lakes basin. Great Lakes Fishery Commission. Miscellaneous Publication. 2010-01.

Yip, S.P., 2002. Sequence variation at the human ABO locus. Annals of Human Genetics. 66: 1-27. 


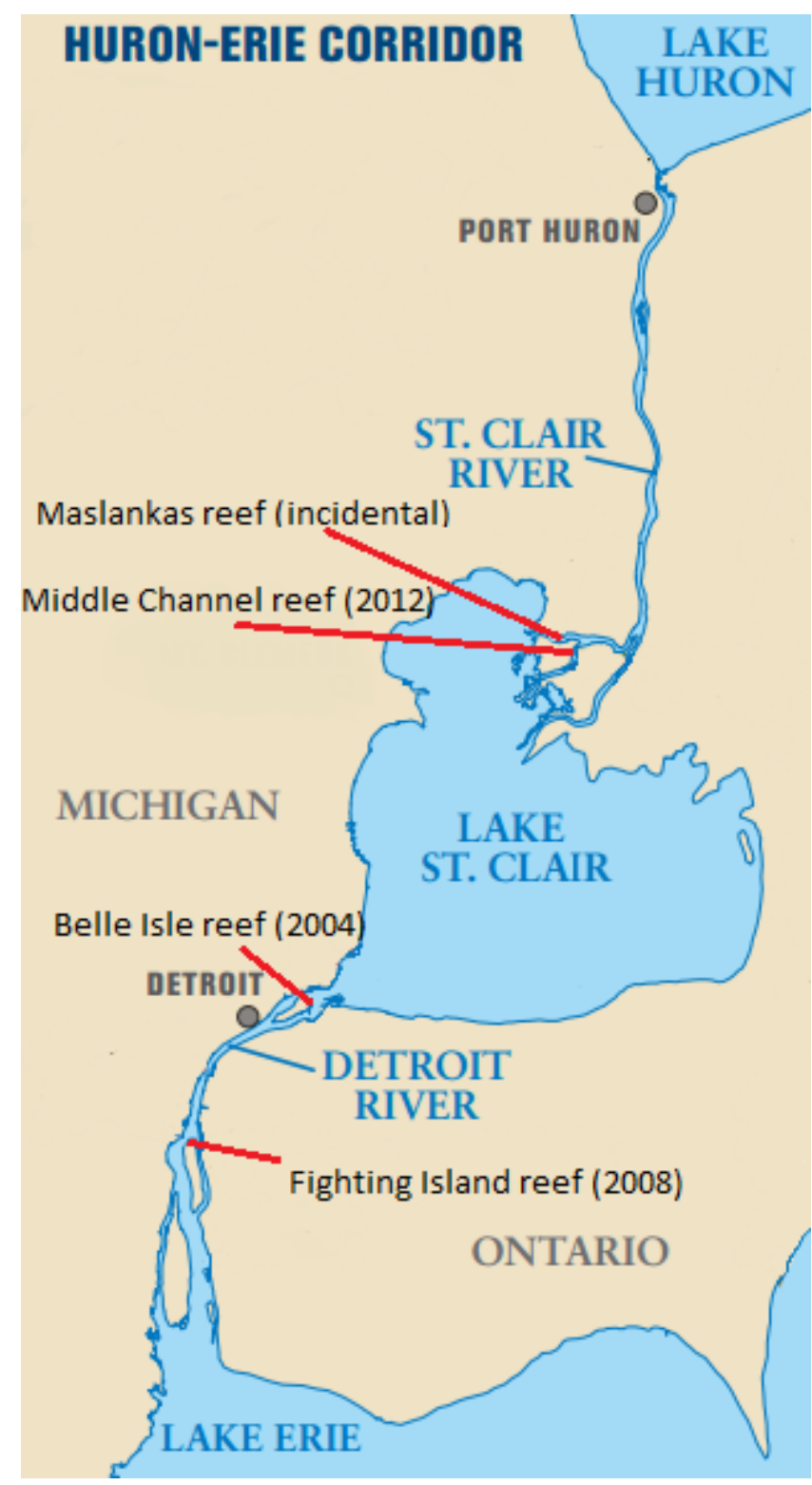

Figure 4. This map shows the position of the three sampled artificial reefs and the year of construction in the St. Clair and Detroit rivers that make up the HEC. (adapted from the Michigan Sea Grant). 


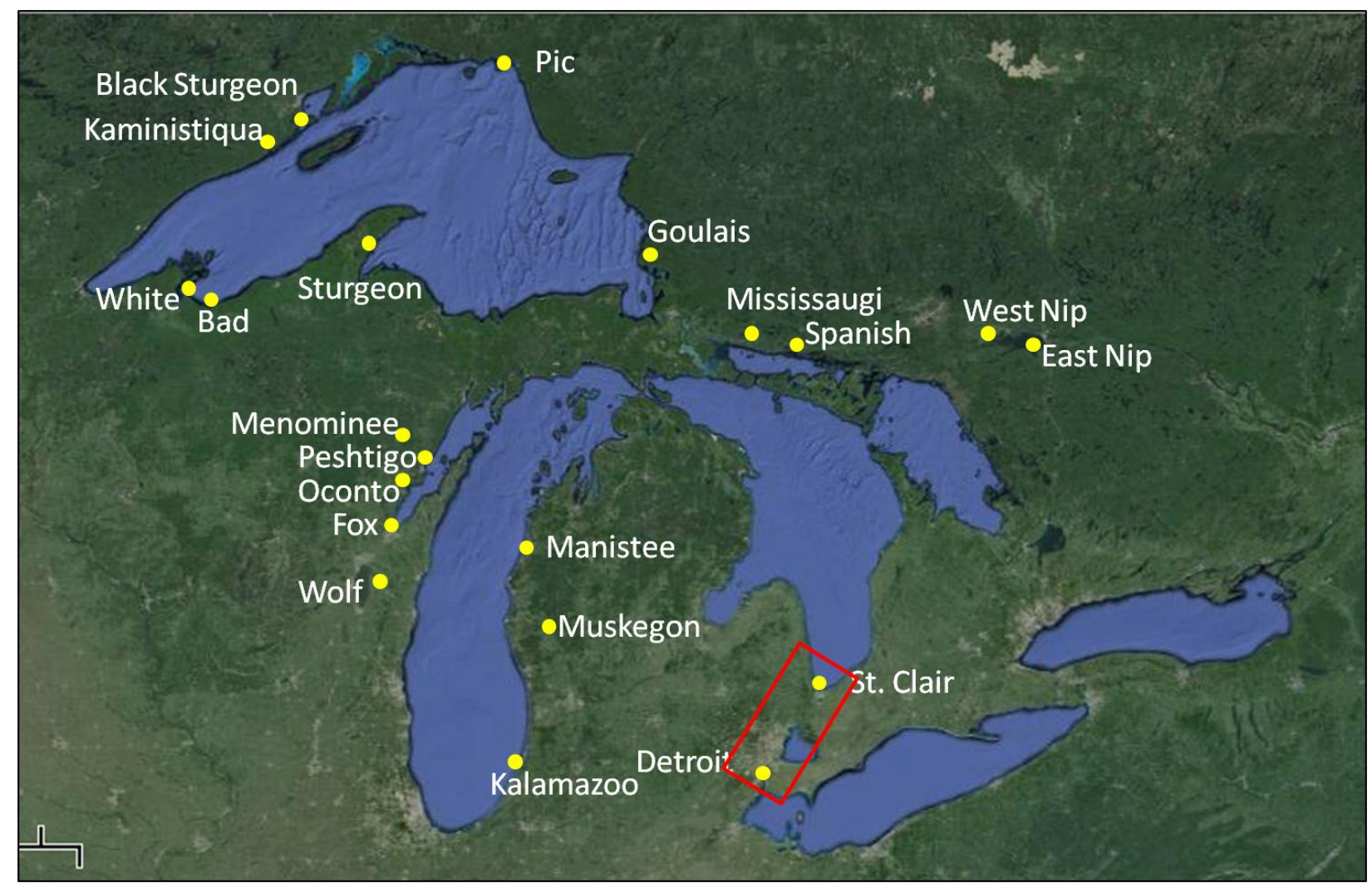

Figure 5. This satellite image shows the location of the 22 potential source populations distributed throughout the upper Great Lakes as described in Welsh et al. (2008). The Northern sites from Kaministiqua to East Nipissing are located in Ontario, Canada. The White down to Wolf are in Wisconsin and the Manistee, Muskegon and Kalamazoo are located in Michigan. Samples from the Detroit and the St. Clair were obtained through permitting between Michigan and Ontario. The red box surrounds the study area: the HEC. 